\title{
Characterization of the sources and processes of organic and inorganic aerosols in New York city with a high-resolution time-of-flight aerosol mass apectrometer
}

\author{
Y.-L. Sun ${ }^{1, *}$, Q. Zhang ${ }^{1}$, J. J. Schwab ${ }^{2}$, K. L. Demerjian ${ }^{2}$, W.-N. Chen ${ }^{3}$, M.-S. Bae ${ }^{2, * *}$, H.-M. Hung ${ }^{4}$, O. Hogrefe ${ }^{2}$, \\ B. Frank ${ }^{5}$, O. V. Rattigan ${ }^{5}$, and Y.-C. Lin ${ }^{3}$ \\ ${ }^{1}$ Department of Environmental Toxicology, University of California, 1 Shields Ave., Davis, California 95616, USA \\ ${ }^{2}$ Atmospheric Sciences Research Center, State University of New York at Albany, Albany, New York, USA \\ ${ }^{3}$ Research Center for Environmental Changes, Academia Sinica, Taipei, Taiwan \\ ${ }^{4}$ Department of Atmospheric Sciences, National Taiwan University, Taipei, Taiwan \\ ${ }^{5}$ Division of Air Resources, New York State Department of Environmental Conservation, Albany, New York, USA \\ *now at: Department of Atmospheric Science, Colorado State University, Fort Collins, CO, USA \\ ** now at: Environmental Engineering Department, Mokpo National University, South of Korea
}

Received: 19 September 2010 - Published in Atmos. Chem. Phys. Discuss.: 4 October 2010

Revised: 11 January 2011 - Accepted: 12 February 2011 - Published: 18 February 2011

\begin{abstract}
Submicron aerosol particles $\left(\mathrm{PM}_{1}\right)$ were measured in-situ using a High-Resolution Time-of-Flight Aerosol Mass Spectrometer during the summer 2009 Field Intensive Study at Queens College in New York, NY. Organic aerosol (OA) and sulfate are the two dominant species, accounting for $54 \%$ and $24 \%$, respectively, of the total $\mathrm{PM}_{1}$ mass. The average mass-based size distribution of OA presents a small mode peaking at $\sim 150 \mathrm{~nm}\left(D_{\text {va }}\right)$ and an accumulation mode $(\sim 550 \mathrm{~nm})$ that is internally mixed with sulfate, nitrate, and ammonium. The diurnal cycles of both sulfate and OA peak between 01:00-02:00 p.m. EST due to photochemical production. The average $( \pm \sigma)$ oxygento-carbon $(\mathrm{O} / \mathrm{C})$, hydrogen-to-carbon $(\mathrm{H} / \mathrm{C})$, and nitrogento-carbon $(\mathrm{N} / \mathrm{C})$ ratios of $\mathrm{OA}$ in NYC are $0.36( \pm 0.09)$, $1.49( \pm 0.08)$, and $0.012( \pm 0.005)$, respectively, corresponding to an average organic mass-to-carbon (OM/OC) ratio of $1.62( \pm 0.11)$. Positive matrix factorization (PMF) of the high resolution mass spectra identified two primary OA (POA) sources, traffic and cooking, and three secondary OA (SOA) components including a highly oxidized, regional low-volatility oxygenated OA $(\mathrm{LV}-\mathrm{OOA} ; \mathrm{O} / \mathrm{C}=0.63)$, a less oxidized, semi-volatile SV-OOA $(\mathrm{O} / \mathrm{C}=0.38)$ and a unique nitrogen-enriched $\mathrm{OA}(\mathrm{NOA} ; \mathrm{N} / \mathrm{C}=0.053)$ characterized with prominent $\mathrm{C}_{\mathrm{x}} \mathrm{H}_{2 \mathrm{x}+2} \mathrm{~N}^{+}$peaks likely from amino compounds. Our results indicate that cooking and traffic
\end{abstract}

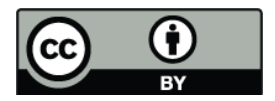

Correspondence to: $\mathrm{Q}$. Zhang

(dkwzhang@ucdavis.edu) are two distinct and mass-equivalent POA sources in NYC, together contributing $\sim 30 \%$ of the total OA mass during this study. The OA composition is dominated by secondary species, especially during high PM events. SV-OOA and LVOOA on average account for $34 \%$ and $30 \%$, respectively, of the total OA mass. The chemical evolution of SOA in NYC appears to progress with a continuous oxidation from SV-OOA to LV-OOA, which is further supported by a gradual increase of $\mathrm{O} / \mathrm{C}$ ratio and a simultaneous decrease of $\mathrm{H} / \mathrm{C}$ ratio in total OOA. Detailed analysis of NOA $(5.8 \%$ of $\mathrm{OA}$ ) presents evidence that organic nitrogen species such as amines might have played an important role in the atmospheric processing of OA in NYC, likely involving both acidbase chemistry and photochemistry. In addition, analysis of air mass trajectories and satellite imagery of aerosol optical depth (AOD) indicates that the high potential source regions of secondary sulfate and aged OA are mainly located in regions to the west and southwest of the city.

\section{Introduction}

Aerosol particles play significant roles in climate change by altering the radiative balance of the Earth's atmosphere directly and indirectly (IPCC, 2007). They also constitute a threat to public health by increasing the risk of morbidity and mortality of sensitive groups (Pope et al., 2002, 2009). Fine particulate matter (PM) in densely populated megacity

Published by Copernicus Publications on behalf of the European Geosciences Union. 
environments are of particular concern for their adverse effects on human health and regional air quality (Molina and Molina, 2004). The New York City (NYC) metropolitan area is one of the most populous megacities in the world and among the most polluted cities in the US by fine PM and ozone (American Lung Association's Report, 2010). It is well known that atmospheric aerosols are influenced by various emission sources and transformation processes. Characterizing the chemical composition and dynamic variations of aerosols in large urban environments such as NYC is important to unravel the complexities of anthropogenic aerosols and supporting health outcome studies (Demerjian and Mohnen, 2008; Wexler and Johnston, 2008).

A number of studies conducted in recent years characterized inorganic species (e.g., sulfate, nitrate, and ammonium), carbonaceous material (e.g., organic and elemental carbon; OC and EC), and trace metal species in aerosols in metropolitan NY (Schwab et al., 2004; Bae et al., 2006; Dutkiewicz et al., 2006; Qin et al., 2006; Venkatachari et al., 2006; Sunder Raman et al., 2008; Rattigan et al., 2010). Sulfate and OC usually dominate fine PM composition in the region. While sulfate is mainly contributed by regional transport, organic aerosol (OA) have contributions from both local and regional accumulation (Dutkiewicz et al., 2004; Lall and Thurston, 2006; Qin et al., 2006). Particulate organic materials can be classified as either primary OA (POA) from direct emissions, e.g., fossil fuel and biomass burning, or secondary OA (SOA) from the oxidation of gas-phase precursors (Kanakidou et al., 2005). SOA has been identified as a major contributor to the fine PM burden in NYC, especially under summertime conditions. Using the EC tracer method, Rattigan et al. (2010) estimated that SOA accounted for $63-73 \%$ and 40 $50 \%$ of total OC during summer and winter, respectively, in South Bronx, NY. In addition, by analyzing ambient aerosol data acquired with an Aerodyne Aerosol Mass Spectrometer (AMS, Canagaratna et al., 2007), Zhang et al. (2007a) reported that oxygenated OA (OOA), a surrogate for SOA, on average accounted for $70 \%$ and $50 \%$ of total OA mass in Queens, NY during summer and winter, respectively.

Two AMS measurements were conducted in summer 2001 (Drewnick et al., 2004a, b) and winter 2004 (Weimer et al., 2006), respectively, on the campus of Queens College (QC) in NYC as part of the $\mathrm{PM}_{2.5}$ Technology Assessment and Characterization Study-NY (PMTACS-NY) - one of the EPA supersite programs (Demerjian and Mohnen, 2008). These real-time, highly time-resolved measurements of the concentrations and size distributions of non-refractory submicron aerosol (NR-PM 1 ) species (i.e., organics, sulfate, nitrate, ammonium, and chloride) offered valuable insights into the chemistry, sources, and evolution processes of fine PM in NYC (Drewnick et al., 2004a, b; Weimer et al., 2006; Demerjian and Mohnen, 2008; Wexler and Johnston, 2008). An interesting observation was a distinct small particle mode $(\sim 70 \mathrm{~nm})$ of organics in summer that was externally mixed with sulfate and nitrate (Drewnick et al., 2004b). This mode appeared to be related to traffic emissions as it intensified during morning rush-hour (Drewnick et al., 2004a). In addition, significant differences in aerosol composition and size distributions were observed in winter at the same site due to different meteorological conditions and photochemical processing (Weimer et al., 2006).

The AMS used during PMTACS-NY 2001 and 2004 was equipped with a Quadrupole mass spectrometer(i.e., QAMS; Jayne et al., 2000) which generates unit mass resolution (UMR) spectra. In summer 2009 we returned to the same site with a new advanced version of the AMS - a HighResolution Time-of-Flight AMS (HR-ToF-AMS, termed as HR-AMS hereafter) (DeCarlo et al., 2006). Compared to the Q-AMS, the HR-AMS is significantly improved on chemical resolution and sensitivity. In particular, the high $\mathrm{m} / \mathrm{z}$ resolution of the HR-AMS allows most ion fragments, especially those at low $m / z$ 's $(<100)$, to be resolved and their nominal elemental compositions (i.e., the ratios among carbon $(\mathrm{C})$, hydrogen $(\mathrm{H})$, oxygen $(\mathrm{O})$, and nitrogen $(\mathrm{N})$ ) of $\mathrm{OA}$ to be determined (Aiken et al., 2008). Here we report the main findings from this study, including (1) evaluation of HR-AMS based on the comparisons of measurements with collocated instruments; (2) mass concentrations, size distributions, chemical composition, and temporal and diurnal variations of $\mathrm{PM}_{1}$ species; (3) elemental composition of $\mathrm{OA}$; and (4) characteristics and dynamic variations of OA components determined via Positive Matrix Factorization (PMF) of the high-resolution mass spectra (HRMS). Based on these results, the sources and processes of organic and inorganic aerosol components in NYC are also discussed.

\section{Methods}

\subsection{Sampling site and instrumentation}

This study took place from 13 July through 3 August 2009 on the campus of QC $\left(40.74^{\circ} \mathrm{N}, 73.82^{\circ} \mathrm{W}, \sim 25 \mathrm{~m}\right.$ a.s.l.; Fig. S1 in the Supplement). The HR-AMS measurements were conducted inside the state-of-the-art Atmospheric Sciences Research Center Mobile Laboratory (ASRC-ML) (Schwab et al., 2010) along with various fast-response aerosol and gas instruments. These instruments include a DMT singlewavelength Photoacoustic Soot Spectrometer (PASS-1), a TSI Fast Mobility Particle Sizer (FMPS, Model 3091, 5.6$560 \mathrm{~nm})$ spectrometer, a TSI water Condensation Particle Counter (CPC, Model 3781), an Aerodyne Quantum Cascade Laser (QCL) Spectrometer for measurements of formaldehyde and $\mathrm{NO}_{2}$, a Li-COR $\mathrm{CO}_{2}$ analyzer, a BTEX analyzer for benzene, toluene, ethylbenzene, and xylenes, and $2 \mathrm{~B}$ technologies analyzers for $\mathrm{O}_{3}, \mathrm{NO}$, and $\mathrm{NO}_{2}$. The ASRC-ML was parked at Lot 6 (Site B in Fig. S1) during this study except for two mornings on 28 and 30 July, and two evenings on 27 July and 1 August when it was moved to Lot 15 (Site C in Fig. S1) to measure near-road traffic plumes. Lot 6 is located 
approximately $500 \mathrm{~m}$ south to the Long Island Expressway (LIE, I-495) and $1.2 \mathrm{~km}$ east to the Van Wyck Expressway (I-678), two high-traffic highways in the NYC metropolitan area. Lot 15 is on the immediate south side of I-495 and $\sim 500 \mathrm{~m}$ to the northeast of Lot 6 . During part of this study, an Aerodyne Mobile Laboratory was also deployed, in which a novel Soot Particle-AMS (SP-AMS) was operated alongside a number of aerosol and gas instruments.

In addition to measurements from the mobile facilities, aerosol and gas species were also measured inside a onestory building (Site A in Fig. S1) situated at $\sim 140 \mathrm{~m}$ north of Lot 6. This was the same sampling site for the PMTACSNY 2001 summer and 2004 winter campaigns. Detailed descriptions of this site are given in Drewnick et al. (2004a) and Weimer et al. (2006). A key instrument deployed at Site A is a Particle-into-Liquid Sampler (PILS) coupled with two Metrohm Compact 761 Ion Chromatography (IC) systems (Herisau, Switzerland). The IC systems were equipped with an A Supp 5-250 and a C 4 column, respectively, for in-situ, simultaneous measurements of anions and cations at $30 \mathrm{~min}$ time interval. Ambient air was sampled into the PILS, in sequence, after a URG PM 2.5 cyclone, a VOC denuder, and two URG 2000 annular glass denuders coated with sodium carbonate and citric acid to remove acidic and basic gases, respectively. The IC systems were calibrated every 3-5 days, and the denuders were regenerated every week. In order to account for volatile losses, a correction factor of $1.14(=/ 0.88)$ suggested by Sorooshian et al. (2006) was applied for ammonium quantification.

In addition to the PILS-IC, other aerosol instruments deployed in the building include a Sunset Lab OC/EC Analyzer, a long- and a nano- Scanning Mobility Particle Sizer (SMPS), a Thermo Electron 5020 Sulfate Particulate Analyzer (SPA), a Tapered Element Oscillating Microbalance (TEOM), and an Aerodyne Aerosol Chemical Speciation Monitor (ACSM). Note that the Sunset Lab OC/EC Analyzer provides an optical measurement of EC (denoted as optical EC) by laser transmission in addition to the standard thermal measurement of EC (Rattigan et al., 2010). The optical EC shows tight correlation with the thermal EC $\left(r^{2}=0.86\right.$, slope $=0.93)$ and also very good correlation with the light absorption coefficient $\left(B_{\mathrm{abs}}, r^{2}=0.86\right)$ from DMT PASS-1 measurements. Here we use the optical EC due to its high time resolution (1-min) and hence a better characterization of aerosol evolution. All the EC data cited in this study refer to the optical EC unless otherwise noted, while the EC values quoted from other studies refer to the thermal EC.

All the data in this study are reported at ambient temperature and pressure $(\sim 101 \mathrm{kPa})$ conditions in Eastern Standard Time (EST), which equals Coordinated Universal Time (UTC) minus $5 \mathrm{~h}$ or local time (i.e., East Daylight Time EDT) minus $1 \mathrm{~h}$.

\subsection{HR-AMS operation}

Ambient air was sampled isokinetically into the HR-AMS from a 1.0 inch (outer diameter) stainless steel tube with an inline $\mathrm{PM}_{2.5}$ cyclone (URG-2000-30EH). The inlet of sampling line was positioned on the top of ASRC-ML at $\sim 2 \mathrm{~m}$ above the ground. The residence time of air between the inlet and the HR-AMS was estimated at $\sim 5 \mathrm{~s}$. The HR-AMS was operated under the " $\mathrm{V}$ " and "W" ion optical modes alternatively every $5 \mathrm{~min}$. The V-mode is more sensitive while the $\mathrm{W}$-mode has higher mass resolution. Under V-mode operation, the AMS cycled through the mass spectrum (MS) mode and the particle time-of-flight (PToF) mode every $30 \mathrm{~s}$, spending $10 \mathrm{~s}$ and $20 \mathrm{~s}$, respectively, in each mode. Size distribution data are reported in units of mass-weighted aerodynamic diameter. No PToF data were sampled in W-mode due to limited signal-to-noise $(\mathrm{S} / \mathrm{N})$ ratio. However, the high mass resolution ( 5000-6000) of W-mode allows us to determine the ion-specific mass spectra and thus the elemental compositions of OA (DeCarlo et al., 2006; Aiken et al., 2008). The HR-AMS was calibrated for ionization efficiency (IE) and particle sizing at the beginning and in the middle of this study following the standard protocols (Jayne et al., 2000; Jimenez et al., 2003; Drewnick et al., 2005). The detection limits (DLs) of NR-PM 1 species were determined as 3 times the standard deviations $(3 \sigma)$ of the corresponding signals in particle-free ambient air through a HEPA filter (Zhang et al., 2005b). The 5-min DLs of organics, sulfate, nitrate, ammonium, and chloride are $57,5,4,23$, and $5 \mathrm{ng} \mathrm{m}^{-3}$ respectively for V-mode and $110,24,30,151$, and $22 \mathrm{ng} \mathrm{m}^{-3}$ respectively for $\mathrm{W}$-mode, which are close to the values reported in previous HR-AMS studies (DeCarlo et al., 2006; Sun et al., 2009).

\subsection{HR-AMS data analysis}

\subsubsection{Standard data analysis}

The mass concentrations and size distributions of NR-PM species were analyzed using the standard AMS data analysis software (SQUIRREL v1.46, Sueper, 2010) written in Igor Pro 6.12A (Wavemetrics, Lake Oswego, OR). A collection efficiency (CE) was introduced to account for the incomplete detection of aerosol species due to particle bounce at the vaporizer $\left(E_{\mathrm{b}}\right)$ (Matthew et al., 2008) and/or partial transmission of particles by the lens (Huffman et al., 2005). Previous studies have shown that the particle loss is mainly due to $E_{\mathrm{b}}$ which is primarily dependent on particle phase and composition (Matthew et al., 2008). A CE $=0.5$ has been widely found to be representative for ambient particles in many AMS studies (Canagaratna et al. 2007 and references therein). High CE values were also observed for the ambient particles with high fraction of nitrate (Crosier et al., 2007; Matthew et al., 2008), high acidity (Quinn et al., 2006; Kleinman et al., 2007), high particle phase water content or 
high organic liquid content (Matthew et al., 2008). Given that the aerosol particles in this study are overall neutralized (see Sect. 3.5.4) and that ammonium nitrate accounts for a minor fraction of total NR-PM 1 mass for most of time, a CE $=0.5$ is used for the AMS quantitative analysis. The value of 0.5 was further validated based on inter-comparisons with collocated measurements (see Sect. 3.1) and is consistent with the CE values observed in previous AMS campaigns at the same site (Drewnick et al., 2003, 2004a; Hogrefe et al., 2004; Weimer et al., 2006). However, using a constant CE value may introduce an uncertainty of $\sim 20-30 \%$. Relative ionization efficiencies (RIEs) of 1.4 for organics, 1.2 for sulfate, 1.1 for nitrate, and 1.3 for chloride were used as previously reported .(Allan et al., 2003b; Jimenez et al., 2003). The RIE for ammonium was determined at 4.0 based on the analysis of pure $\mathrm{NH}_{4} \mathrm{NO}_{3}$ particles during this study.

\subsubsection{High resolution mass spectra analysis}

The HRMS of both V- and W-mode were analyzed using the PIKA v1.06 - software toolkit downloaded at http://cires.colorado.edu/jimenez-group/ ToFAMSResources/ToFSoftware/index.html. The W-mode spectra were analyzed to determine the elemental compositions of ion fragments, and subsequently the $\mathrm{H} / \mathrm{C}, \mathrm{O} / \mathrm{C}$, N/C, and OM/OC ratios of OA (Aiken et al., 2008). Since the organic $\mathrm{H}_{2} \mathrm{O}^{+}, \mathrm{HO}^{+}, \mathrm{O}^{+}$, and $\mathrm{CO}^{+}$signals were not measured directly due to large uncertainties, they were scaled according to the intensities of the organic $\mathrm{CO}_{2}^{+}$ signal using the ratios suggested by Aiken et al. (2008), i.e., $\mathrm{CO}^{+}=\mathrm{CO}_{2}^{+}, \mathrm{H}_{2} \mathrm{O}^{+}=0.225 \mathrm{CO}_{2}^{+}, \mathrm{HO}^{+}=0.25 \mathrm{H}_{2} \mathrm{O}^{+}$ and $\mathrm{O}^{+}=0.04 \mathrm{H}_{2} \mathrm{O}^{+}$. Additionally, elemental analysis was also performed to the V-mode spectra using the same ion fragments identified for the $\mathrm{W}$-mode spectra. Very similar $\mathrm{O} / \mathrm{C}, \mathrm{H} / \mathrm{C}$, and $\mathrm{OM} / \mathrm{OC}$ ratios as those from $\mathrm{W}$-mode were observed. However, the $\mathrm{V}$-mode $\mathrm{N} / \mathrm{C}$ ratios are on average a factor of 2 different from the $\mathrm{W}$-mode results, due to larger uncertainties in quantifying $\mathrm{C}_{\mathrm{x}} \mathrm{H}_{\mathrm{y}} \mathrm{N}_{\mathrm{p}}^{+}$ions using the lower resolution V-mode spectra.

\subsubsection{PMF analysis of high resolution mass spectra}

PMF analysis (Paatero and Tapper, 1994) was performed to the HRMS, i.e., the ion-speciated W-mode spectra, using the PMF Evaluation Toolkit (PET) v2.02 (Ulbrich et al., 2009). The error matrix for PMF analysis was determined based on propagation of errors of Poisson counting statistics and electronic noise (DeCarlo et al., 2010). The peak fitting errors calculated from the residuals of PIKA fitting were also considered for small ions situated in close proximity to large ions. Ions with $\mathrm{S} / \mathrm{N}$ ratio $<0.2$ were removed from the HRMS data and error matrices before PMF analysis. Excluding these noisy ions improves the differentiation of OA components, but has little impact on the mass concentrations since they together account for only $\sim 2 \%$ of total OA signal.
The "weak" ions with $\mathrm{S} / \mathrm{N}$ between 0.2 and 2 were downweighed by increasing their errors by a factor of 2 (Paatero and Hopke, 2003; Ulbrich et al., 2009). In addition, $\mathrm{H}_{2} \mathrm{O}^{+}$, $\mathrm{HO}^{+}, \mathrm{O}^{+}$, and $\mathrm{CO}^{+}$were removed from the data and error matrices before the PMF analysis because they were determined according to the relationship with $\mathrm{CO}_{2}^{+}$. Including these ions may introduce additional weight to $\mathrm{CO}_{2}^{+}$(Ulbrich et al., 2009). They were inserted back into the mass spectral matrix after the PMF analysis.

A summary of the PMF results is presented in Fig. S2. After an extensive evaluation of the mass spectral profiles and time series of different number of factors and the rotational forcing parameter, fPeak, the 5-factor solution with fPeak $=0\left(Q / Q_{\text {expected }}=3.6\right)$ was chosen. The OA components of the 5-factor solution solved under different fPeak values show very similar mass spectral patterns and time series (Fig. S2). The direct comparisons of the mass spectra and time series of 4-factor and 6-factor solution are shown in Fig. S3. The 4-factor solution does not resolve the small, yet distinct, fifth factor ( $\sim 6 \%$ of total OA) (see Sect. 3.5.4 for details). The 6-factor solution splits the semi-volatile OA (SV-OOA) into two components for which we cannot offer a physically meaningful interpretation. We therefore choose the 5-factor solution. A detailed list of reasons for the selection of the 5-factor solution is given in Table S1.

\subsection{Air mass trajectories and aerosol optical depth}

3-day back trajectories arriving at QC were calculated every $1 \mathrm{~h}$ over the time period of this study using the National Oceanic and Atmospheric Administration (NOAA) HYSPLIT 4.8 model (Draxler and Rolph, 2003) and the meteorological input from Air Resources Laboratory FNL data archive. 490 trajectories in total were obtained. These trajectories were then categorized into four clusters, i.e., cluster 1 from northwest ( $7.3 \%$ of time), cluster 2 from west (37.3\% of time), cluster 3 from the Atlantic Ocean (24.5\% of time), and cluster 4 from southwest ( $30.8 \%$ of time), using the trajectory cluster analysis of the HYSPLIT 4.8 model.

Aerosol optical depth (AOD) was retrieved from the observations at wavelength of $550 \mathrm{~nm}$ made by National Aeronautics and Space Administration (NASA) Moderate Resolution Imaging Spectroradiometer (MODIS) onboard the Terra satellite. The Collection 5 level 2 data was used in this study (http://ladsweb.nascom.nasa.gov/browse_images/ 12_browser.html?form=AADS $\backslash \&$ browseType=Level+2).

The algorithm of retrieval and validation of retrieved AOD is described in detail in Remer et al. (2005). 

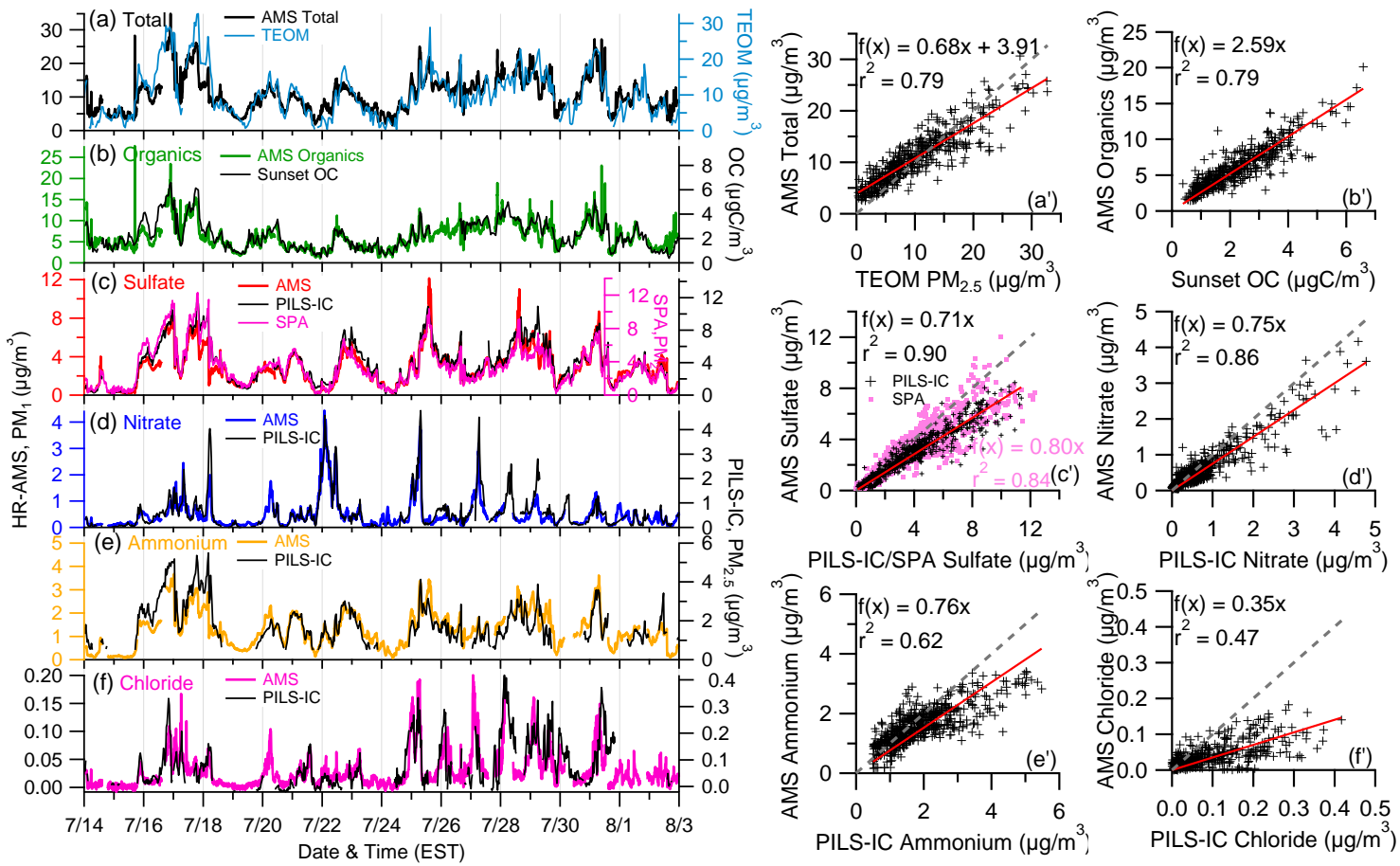

Fig. 1. Inter-comparisons between the NR-PM 1 mass concentrations measured by the HR-MS vs. the data acquired by collocated instruments: (a) total (=organics + sulfate + nitrate + ammonium + chloride) vs. $\mathrm{PM}_{2.5}$ mass by a TEOM, (b) organics vs. PM 2.5 OC by a Sunset Lab OC/EC Analyzer, and (c-f) sulfate, nitrate, ammonium, and chloride vs. those measured by a PILS-IC. (c) also shows the comparison with $\mathrm{PM}_{2.5}$ sulfate by a SPA. (a'-f') are the scatter plots with the linear regression parameters and the 1:1 line (dash line) shown for the comparisons.

\section{Results and discussions}

\subsection{Inter-comparisons}

Figure 1 shows the inter-comparisons of measurements by the HR-AMS and other collocated instruments. Overall, the HR-AMS results correlate well with those of TEOM, PILS-IC, SPA, and Sunset Lab OC/EC Analyzer $\left(r^{2}=0.47-0.90\right)$. NR-PM 1 in total (=sulfate + nitrate + organics + ammonium + chloride) reports $68 \%$ of the TEOM PM 2.5 mass, mainly because the HR-AMS only detects $\mathrm{PM}_{1}$ and does not respond to refractory components such as black carbon and crustal materials. An intercept of $3.91 \mathrm{\mu g} \mathrm{m}^{-3}$ for the linear regression of AMS total vs. TEOM mass is likely due to the losses of semi-volatile materials at $50{ }^{\circ} \mathrm{C}$ inside TEOM (Eatough et al., 2003). The AMS sulfate, nitrate, and ammonium account for $\sim 71-76 \%$ of those in $\mathrm{PM}_{2.5}$ from PILS-IC measurements with $r^{2}$ ranging between $0.62-0.90$. These comparisons are consistent with previous observations at other urban sites, e.g., Pittsburgh (Zhang et al., 2005b),Tokyo, Japan (Takegawa et al., 2005), Toronto, Canada (Buset et al., 2006), and Mexico City (Salcedo et al., 2006). Note that during PMTACS-NY 2001 and 2004 the correlations between Q-AMS and PILSIC measurements were close to $1: 1$ for both sulfate and ni- trate (Drewnick et al., 2003; Drewnick et al., 2004a; Weimer et al., 2006). However, a CE value of 0.43 was applied in those studies vs. $\mathrm{CE}=0.5$ used in this analysis.

While the chloride concentrations measured by the HRAMS correlate with those by the PILS-IC $\left(r^{2}=0.47\right.$, Fig. 1f'), the HR-AMS on average reports only $\sim 35 \%$ of the chloride measured by PILS. In addition, there are times when the AMS-chloride is much lower than the PILS-chloride (e.g., 09:00 a.m.-20:00 p.m., 31 July, Fig. 1f). This is probably because the HR-AMS measures primarily NR-chloride (e.g., in the form of $\mathrm{NH}_{4} \mathrm{Cl}$ ) and is insensitive to refractory species such as $\mathrm{NaCl}$ and $\mathrm{KCl}$ at its vaporizer temperature of $600^{\circ} \mathrm{C}$. Indeed, significantly elevated signals of chloride (e.g., ${ }^{35} \mathrm{Cl}^{+}$and ${ }^{37} \mathrm{Cl}^{+}$) are observed in the "closed" (or "background") mass spectra acquired during this study, indicating the detection of considerable amounts of refractorychloride. Refractory species, such as lead, evaporate slowly, yet continuously, on the AMS oven and thus show elevated signals in the "background" spectra (Salcedo et al., 2010). Given the proximity of NYC to the Atlantic Ocean, significant amounts of refractory-chloride are likely present in airborne $\mathrm{PM}_{1}$.

Although the HR-AMS organic concentrations show tight correlation with the OC concentrations measured by a Sunset Lab OC/EC Analyzer $\left(r^{2}=0.79\right)$, the linear regression slope 
of 2.59 is higher than the average OM/OC ratio of 1.62 determined via elemental analysis of the HRMS (Sect. 3.3). The typical OM/OC ratios observed at urban sites range $\sim 1.6-$ 1.8 (Turpin and Lim, 2001; Takegawa et al., 2005; Zhang et al., 2005b; Bae et al., 2006; Aiken et al., 2008). Weimer et al. (2006) also observed relatively high slopes of 2.062.72 in winter 2004 at QC comparing Q-AMS vs. Sunset OC measurements. Possible reasons for this discrepancy include: (1) evaporative losses of semi-volatile species during the carbon analysis, which is consistent with the observation that semi-volatile organic species compose a large fraction of OA in NYC (see Sect. 3.5.1), (2) "over-correction" of the OC data using the blank filter values (Bae et al., 2006), and (3) underestimation of the CE value for organics. Note that in a previous AMS study in Pittsburgh, Zhang et al. (2005b) applied a $C E$ value of 0.7 for organics and $C E=0.5$ for inorganic species based on the observations that the smaller mode organics appeared to be externally mixed with $\mathrm{SO}_{4}^{2-}$, $\mathrm{NO}_{3}^{-}$and $\mathrm{NH}_{4}^{+}$and that the small mode particles appeared to be primarily sooty combustion particles for which the transmission and detection is close to 1 in the AMS according to laboratory studies (Slowik et al., 2004). Although the chemically resolved size distributions of this study also suggested external mixtures of the small mode organics and the inorganics, we did not see clear indication that the $\mathrm{CE}$ values should vary significantly according to particle size or composition. For example, the correlations between AMS OM and Sunset Lab OC are independent on the mass fraction of the small mode organics or the fraction of hydrocarbon-like $\mathrm{OA}$ (Fig. S4). Given that using $\mathrm{CE}=0.5$ for inorganic species is supported well by the intercomparisons with other particle measurements (Fig. 1) and that the major fraction of the organics appears to be internally mixed with the inorganics, our decision of using $\mathrm{CE}=0.5$ for all species seems to be valid and the organic mass concentrations reported in this study are unlikely biased.

\subsection{Mass concentration, composition, and diurnal variation of submicron aerosol particles}

Figure 2 shows the time variations of total $\mathrm{PM}_{1}$ mass, the mass fractional contributions of individual species, and the meteorological conditions during the entire campaign. The $\mathrm{PM}_{1}$ concentration and composition vary dynamically with high aerosol loadings generally associated with southerly wind. Low $\mathrm{PM}_{1}$ loading periods typically occur with northwesterly wind. The total mass concentrations of $\mathrm{PM}_{1}$ (including EC) vary between 2.08 and $35.8 \mu \mathrm{g} \mathrm{m}^{-3}$ during this study. Organics frequently comprise the largest fraction of $\mathrm{PM}_{1}$ with sulfate being the second largest (Fig. 2d). On average, organics and sulfate account for $54.3 \%$ (24.5-96.5\%) and $24.2 \%(0.7-54.8 \%)$, respectively, of $\mathrm{PM}_{1}$ mass (Table 1). The dominance of organics and sulfate is similar to previous observations at the same site in summer 2001 (Drewnick et al., 2004a). The average loading of $\mathrm{PM}_{1}$ is also
Table 1. Summary of the mass concentrations $\left(\mu \mathrm{g} \mathrm{m}^{-3}\right)$ of NR$\mathrm{PM}_{1}$ species, OA components, and EC.

\begin{tabular}{lrrrrr}
\hline & Average & $1 \sigma$ & Median & Minimum & Maximum \\
\hline Organics & 6.34 & 3.2 & 5.76 & 1.03 & 27.7 \\
LV-OOA & 1.93 & 1.38 & 1.72 & 0.06 & 7.63 \\
SV-OOA & 2.14 & 1.86 & 1.66 & 0.04 & 8.83 \\
NOA & 0.37 & 0.55 & 0.76 & 0.00 & 3.66 \\
COA & 1.02 & 0.96 & 0.63 & 0.01 & 5.61 \\
HOA & 0.91 & 0.91 & 0.21 & 0.08 & 6.54 \\
Sulfate & 2.82 & 1.81 & 2.71 & 0.13 & 12.1 \\
Nitrate & 0.49 & 0.54 & 0.33 & 0.03 & 4.44 \\
Ammonium & 1.28 & 0.73 & 1.25 & 0.06 & 3.67 \\
Chloride & 0.03 & 0.03 & 0.02 & <D. L. ${ }^{\mathrm{a}}$ & 0.20 \\
EC & 0.70 & 0.54 & 0.57 & $<$ D. L. & 6.21 \\
Total $^{\mathrm{b}}$ & 11.7 & 5.43 & 11.1 & 2.08 & 35.8 \\
\hline
\end{tabular}

a Detection Limit.

b Total $=$ organics + sulfate + nitrate + ammonium + chloride + EC.

similar between this study $\left(11.7 \mu \mathrm{g} \mathrm{m}^{-3}\right)$ and summer 2001 $\left(12.5 \mu \mathrm{g} \mathrm{m}^{-3}\right)$ (Drewnick et al., 2004a; Weimer et al., 2006). However, on average sulfate is $\sim 31 \%$ lower and organics $\sim 9 \%$ higher in 2009 compared to 2001. The decrease in sulfate is consistent with the statewide reduction in $\mathrm{SO}_{2}$ emissions in New York over the years (e.g., by more than a factor of 2 from 2001 to 2009; http://www.dec.ny.gov/chemical/ 54358.html), for which the introduction of ultra low sulfur diesel fuel starting in 2006 is part of the mitigation measures. However, differences in wind patterns between the 2001 and 2009 study periods might have also played an important role for the concentration differences.

While nitrate overall represents a minor fraction of $\mathrm{PM}_{1}(4.2 \%$ ), high fraction of nitrate (up to $30-40 \%$ of $\mathrm{PM}_{1}$ ) are observed during some time periods (e.g., 02:0004:00 a.m., 22 July, Fig. 2). The average EC concentration of $0.70 \mu \mathrm{g} \mathrm{m}^{-3}\left(6 \%\right.$ of $\left.\mathrm{PM}_{1}\right)$ is close to the values observed in NYC previously, e.g., $0.75 \pm 0.20 \mu \mathrm{g} \mathrm{m}^{-3}$ from 2002-2004 at QC (Bae et al., 2006) and 0.5-1.4 $\mu \mathrm{g} \mathrm{m}^{-3}$ from 20062008 at South Bronx (Rattigan et al., 2010). In comparison, the EC concentrations observed in rural NY were typically 2-4 times lower, e.g., $0.18 \pm 0.20 \mu \mathrm{g} \mathrm{m}^{-3}$ at Pinnacle State Park (Bae et al., 2006) and 0.31 and $0.36 \mu \mathrm{g} \mathrm{m}^{-3}$, respectively, at Potsdam and Stockton (Sunder Raman et al., 2008). A weekday vs. weekend comparison of the concentrations of NR-PM 1 species shows almost no difference (1.5\%) for sulfate yet $\sim 8-28 \%$ lower concentrations for the other NR species during weekend. EC shows the largest decrease (on average 35\%) during weekend, similar to the observations made in South Bronx (Rattigan et al., 2010). The average diurnal cycles of aerosol species are shown in Fig. 3. Organics show a small early morning peak between 05:0006:00 a.m. (i.e., 06:00-07:00 a.m. local time) and a distinct early afternoon peak between 12:00-14:00 p.m. The morning peak correlates with that of EC, which is primarily due 


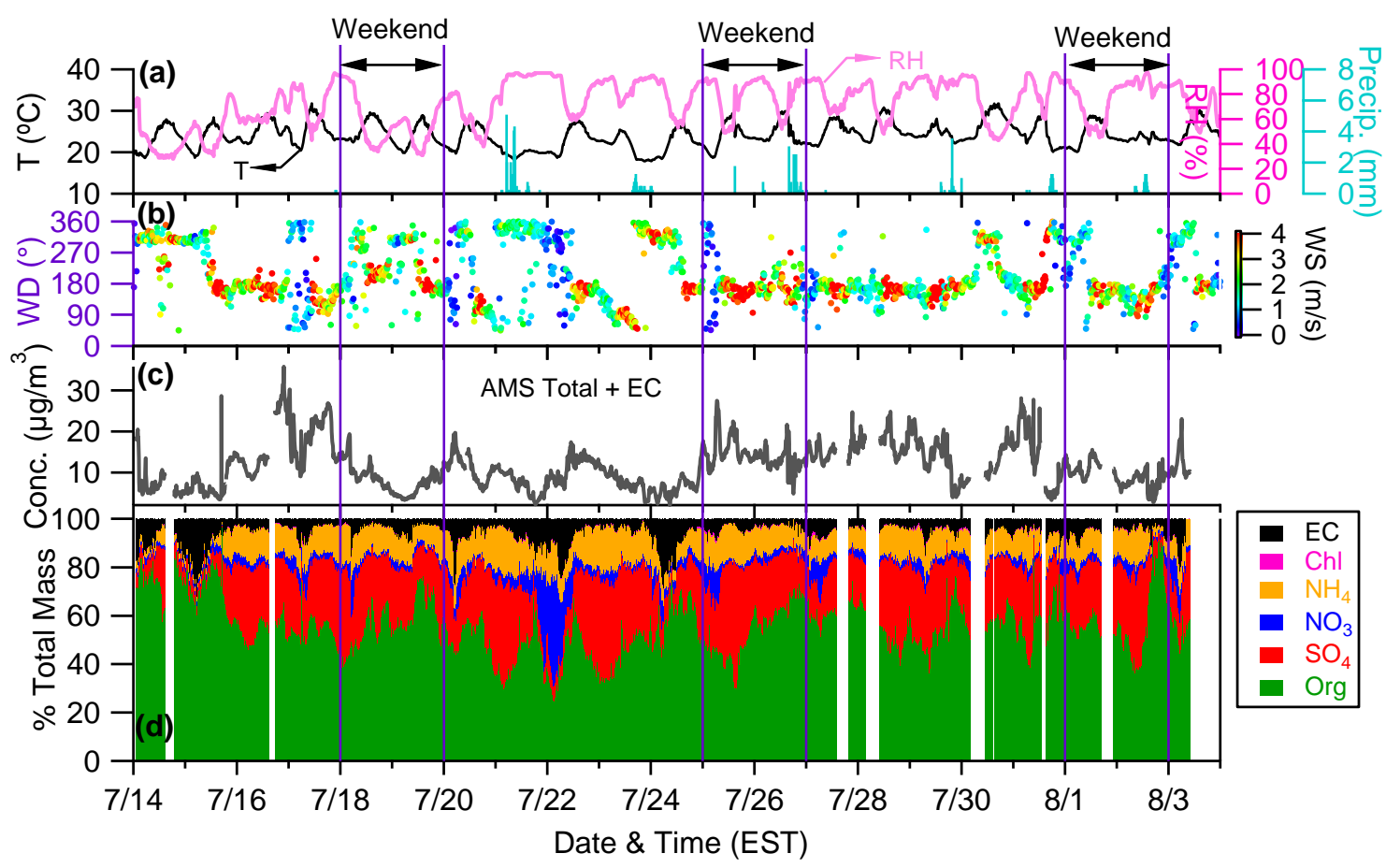

Fig. 2. Time series of (a) relative humidity (RH), temperature (T), and hourly precipitation (Precip), (b) wind direction (WD) colored by wind speed (WS), (c) mass concentration of AMS total + EC, and (d) mass fractions of chemical species in PM $_{1}$.

to local traffic emissions. The early afternoon peak of organics is mostly contributed by oxygenated species as the result of photochemical formation of SOA and by emissions of POA from cooking-related activities as well (Sect. 3.5.3). The high concentration of organics at night is likely due to increased traffic from heavy duty diesel trucks (to avoid commuter traffic; Venkatachari et al., 2006) compounded with less dilution due to shallow boundary layer. Indeed, substantially elevated EC (Fig. 3a) and HOA - a surrogate for traffic related POA (Sect. 3.5.2) - are clearly seen at night.

Sulfate shows an early afternoon peak at $\sim 13: 00$ 14:00 p.m., similar to that observed in summer 2001 Drewnick et al., 2004a). In order to investigate the source of this peak, the diurnal production rate of sulfuric acid was estimated based on the gas phase bi-molecule association reaction of $\mathrm{SO}_{2}+\mathrm{OH}+\mathrm{M} \rightarrow \mathrm{HOSO}_{2}+\mathrm{M}$. The $\mathrm{OH}$ concentration data used for the calculation was acquired in the same month during PMTACS-NY 2001 at the same location (Ren et al., 2003). The calculation formula is presented in Appendix $\mathrm{A}$ and the diurnal profile of the production rate of sulfuric acid is shown in Fig. $4 \mathrm{a}$, in which gaseous $\mathrm{CO}_{2}$ is used as an indicator of dilution associated with changes in boundary layer height. The gas phase production rate of sulfuric acid peaks at early afternoon as sulfate does, counteracting the dilution associated with higher boundary layer that clearly leads to a gradual drop in the concentrations of primary emission species (e.g., $\mathrm{CO}_{2}, \mathrm{NO}_{\mathrm{x}}, \mathrm{EC}$, and HOA) during daytime. The integrated increase of sulfate due to gas phase production of $\mathrm{H}_{2} \mathrm{SO}_{4}$, which is estimated at $\sim 0.35 \mu \mathrm{g} \mathrm{m}{ }^{-3}$ from 08:00 a.m. to 14:00 p.m., is much lower than the observed $\sim 1 \mu \mathrm{g} \mathrm{m}^{-3}$ increase of sulfate (Fig. 4a), indicating that regional transport and/or aqueous processes may have played a significant role controlling sulfate concentration in NYC. Indeed, the relatively flat diurnal pattern and a general trend of multi-day build-up signify the regional influences on sulfate in NYC, consistent with the regional characteristics of sulfate in the northeastern US (Dutkiewicz et al., 2004; Zhang et al., 2005b; Qin et al., 2006).

Both nitrate and chloride show similar diurnal cycles with peak concentrations appearing in early morning (04:00-07:00 a.m., Fig. 3d, f). The diurnal cycle of nitrate is mainly driven by $\mathrm{HNO}_{3}$ production, gas-toparticle partitioning to form ammonium nitrate, and boundary layer dynamics (Seinfeld and Pandis, 2006). Figure $4 \mathrm{~b}$ shows the production rate of $\mathrm{HNO}_{3}$ estimated from the reaction of $\mathrm{NO}_{2}+\mathrm{OH}+\rightarrow \mathrm{HONO}_{2}+\mathrm{M}$, which is the main formation mechanism of nitrate during daytime, and the diurnal profile of the equilibrium constant $\left(K_{\mathrm{p}}\right)$ of $\mathrm{NH}_{3}(\mathrm{~g})+\mathrm{HNO}_{3}(\mathrm{~g}) \leftrightarrow \mathrm{NH}_{4} \mathrm{NO}_{3}$ (s) (see Appendix A for calculations). Note that the formation of $\mathrm{NH}_{4} \mathrm{NO}_{3}(\mathrm{~s})$ is also controlled by the acidity of particles as acidic particles retain very little nitrate (Zhang et al., 2007b). However, since $\mathrm{PM}_{1}$ appears to be bulk neutralized for a large fraction of time during this study (Sect. 3.5.4), the overall influence of aerosol acidity on ammonium nitrate production is very small and the gas-to-particle partitioning of $\mathrm{NH}_{4} \mathrm{NO}_{3}$ is primarily controlled by temperature and RH. 


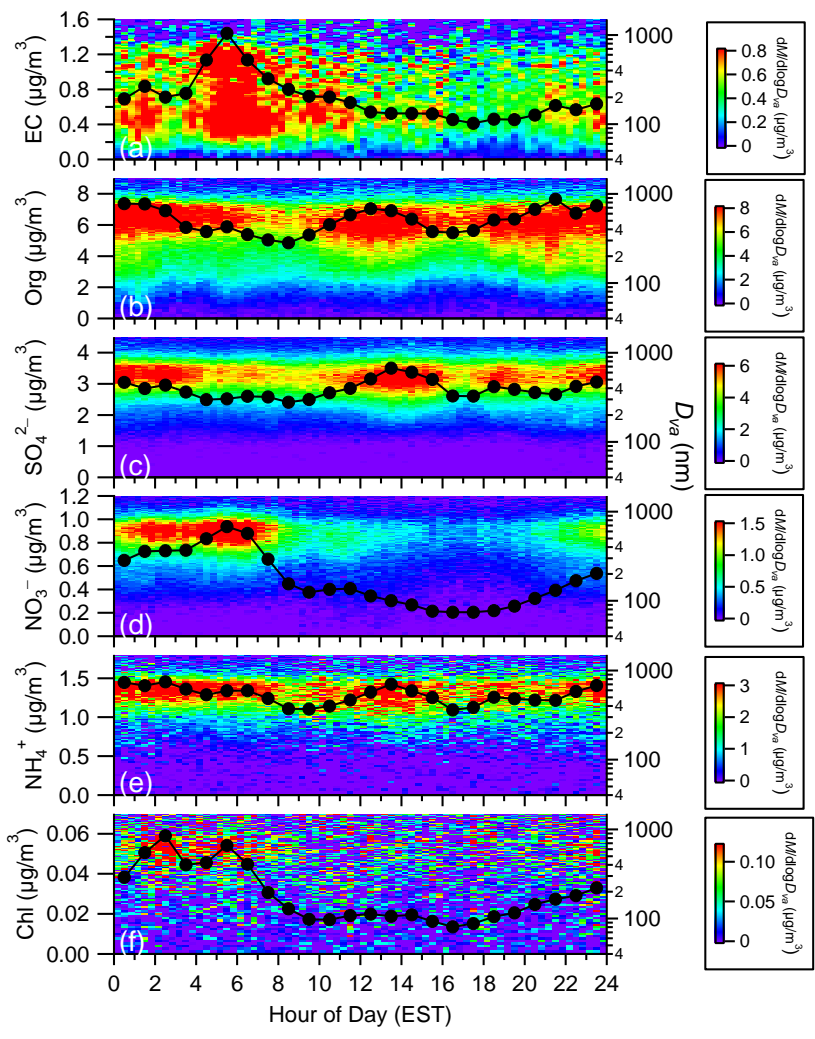

Fig. 3. Diurnal profiles of the mass concentrations (solid black circles) and the size distributions of EC, organics, sulfate, nitrate, ammonium, and chloride.

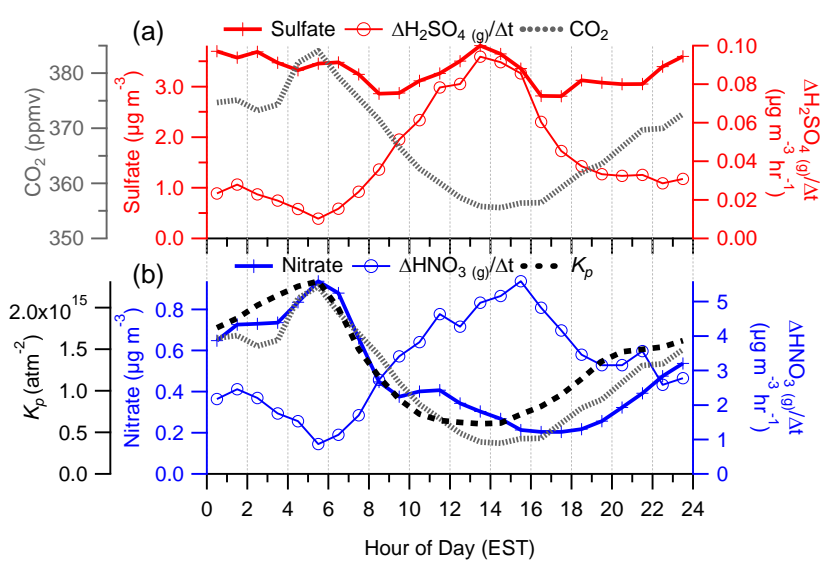

Fig. 4. Diurnal cycles of (a) sulfate, estimated gas phase production rate of $\mathrm{H}_{2} \mathrm{SO}_{4}$, and $\mathrm{CO}_{2}$ and (b) nitrate, estimated gas phase production rate of $\mathrm{HNO}_{3}$, equilibrium constant of $K_{\mathrm{p}}$ for ammonium nitrate, and $\mathrm{CO}_{2}$.

Despite intense daytime production of $\mathrm{HNO}_{3}$ (at peak rate of $5.6 \mu \mathrm{g} \mathrm{m}^{-3} \mathrm{~h}^{-1}$, Fig. $4 \mathrm{~b}$ ), the diurnal cycle of nitrate shows overall similar variation pattern as that of $K_{\mathrm{p}}$, which decreases during daytime and reaches minimum at $\sim 02: 00$ p.m. EST. However, the higher concentrations of nitrate at night
(Fig. 4b), as well as the occurrence of several nighttime elevated nitrate events (Fig. 2d), may also be due to nighttime heterogeneous hydrolysis of $\mathrm{N}_{2} \mathrm{O}_{5}-\mathrm{a}$ reaction product of $\mathrm{NO}_{2}$ and nitrate radical (Brown et al., 2003). The hydrolysis processes is favored by the high $\mathrm{RH}$ at night. These results suggest that gas-to-particle partitioning of $\mathrm{HNO}_{3}$ and nocturnal processing control the diurnal variation of nitrate in NYC. Similar diurnal pattern of nitrate was observed in Pittsburgh (Zhang et al., 2005b), Ontario, Canada (Rupakheti et al., 2005) and at the same site in summer 2001 (Drewnick et al., 2004a). However, significantly different patterns were observed in both Mexico City (Salcedo et al., 2006; Aiken et al., 2009) and Beijing in 2006 (Sun et al., 2010), where daytime photochemical production of $\mathrm{HNO}_{3}$ is much faster likely due to considerably higher $\mathrm{NO}_{\mathrm{x}}$ emissions. The diurnal cycle of ammonium is very similar to the sum of sulfate and nitrate as it presents mainly in the form of ammonium sulfate and ammonium nitrate.

\subsection{Bulk composition and elemental ratios of $\mathrm{OA}$}

Figure 5 shows the average HRMS of OA based on the contributions of elements and ion categories. The $\mathrm{m} / \mathrm{z} 44$ peak, mainly contributed by $\mathrm{CO}_{2}^{+}(92 \%$, Fig. 5c), is the base peak in the spectrum. $\mathrm{m} / \mathrm{z} 57$ ( $\sim 2 \%$ of OA), which has been suggested as an AMS spectral tracer for HOA (Zhang et al., 2005a), is also a significant peak. However, on average only $70 \%$ of signal at $m / z 57$ is the hydrocarbon ion $-\mathrm{C}_{4} \mathrm{H}_{9}^{+}$and the rest $30 \%$ is associated with $\mathrm{C}_{3} \mathrm{H}_{5} \mathrm{O}^{+}$(Fig. 5c). The bulk mass-based composition of OA in NYC is dominated by carbon $(62.1 \%)$ and oxygen $(29.3 \%)$ with a minor contribution from hydrogen $(7.7 \%)$ and nitrogen $(0.8 \%)$. All of the elements peak at $\sim 01: 00$ p.m. due to photochemical production and enhanced cooking emissions despite deeper boundary layer (Fig. S5). A small morning peak of $\mathrm{C}, \mathrm{H}$, and $\mathrm{N}$ occurs between $\sim$ 05:00-06:00 a.m. due to local traffic emissions and shallow boundary layer, consistent with that of EC. In contrast, the average mass fractions of elements show relatively flat diurnal patterns except for slightly higher contributions of $\mathrm{C}$ in the morning and of $\mathrm{O}$ during the afternoon (Fig. 5d). On a daily basis, the $\mathrm{O} / \mathrm{C}$ ratio of $\mathrm{PM}_{1}$ varies between 0.31-0.40 and OM/OC between 1.56-1.67 (Fig. 5e).

The average $( \pm 1 \sigma) \mathrm{OM} / \mathrm{OC}$ ratio for the entire study is $1.62( \pm 0.11)$, which is consistent with the value of $1.6( \pm 0.2)$ suggested for urban aerosols (Turpin and Lim, 2001). The $\mathrm{OM} / \mathrm{OC}$ ratios determined from a multi-year study at QC by comparing the reconstructed $\mathrm{PM}_{2.5}$ mass and $\mathrm{OC}$ vary between 1.27 and 2.01 (Bae et al., 2006). The O/C ratio $(0.36 \pm 0.09)$ of this study is also consistent with AMS observations at other urban sites, e.g., Mexico City (Aiken et al., 2008), Tokyo (Takegawa et al., 2005), and London (Allan et al., 2010). The OM/OC and $\mathrm{O} / \mathrm{C}$ ratios both increase gradually from morning to late afternoon due to enhanced photochemical SOA formation (Fig. 5e). The H/C ratio $(1.49 \pm 0.08)$ shows an opposite diurnal pattern with a 

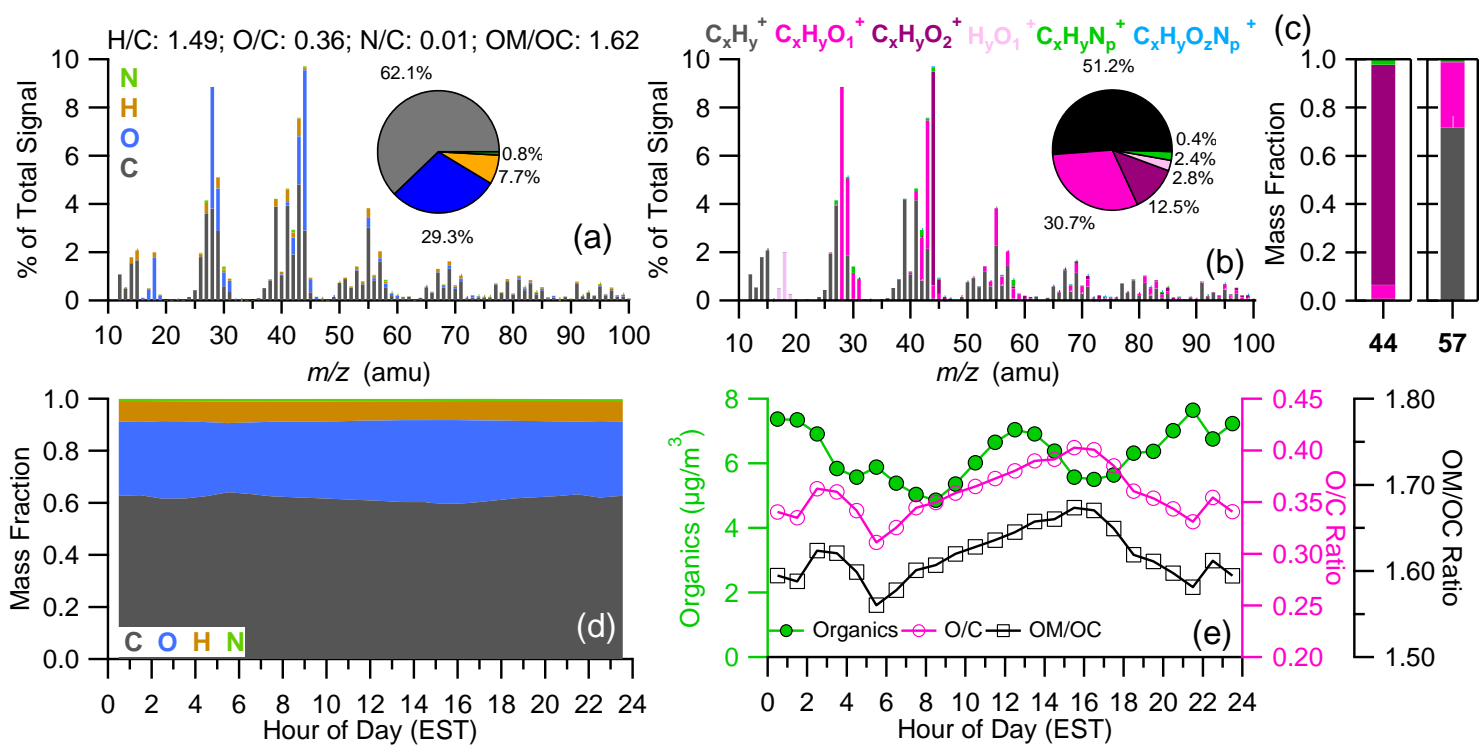

Fig. 5. Average OA spectrum colored by the contributions of (a) elements $(\mathrm{C}, \mathrm{O}, \mathrm{H}$, and $\mathrm{N})$ and (b) six ion categories. (c) The ion compositions of $\mathrm{m} / \mathrm{z} 44$ and 57; (d) diurnal profiles of the mass fractions of elements; and (e) diurnal profiles of organics, O/C and OM/OC ratios. The inset pie charts in (a) and (b) show the average mass fractions of elements and ion categories, respectively. The average elemental and $\mathrm{OM} / \mathrm{OC}$ ratios of $\mathrm{OA}$ are also shown in the legend of (a).

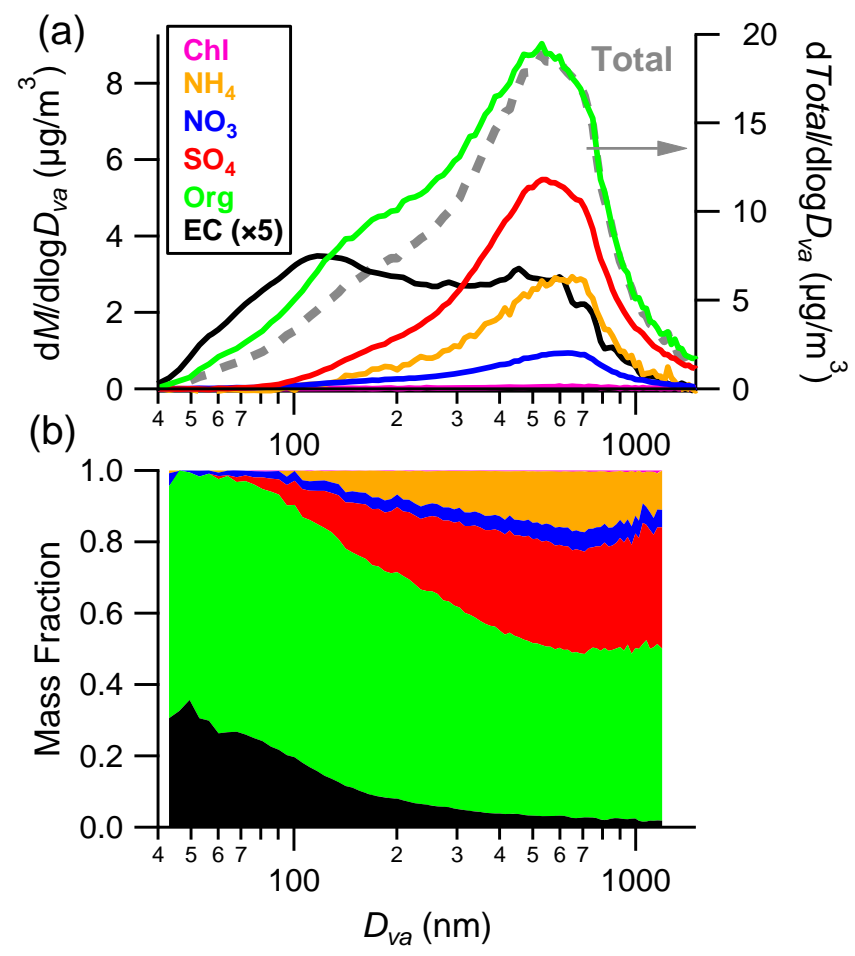

Fig. 6. Average size distributions of (a) mass concentrations and (b) fractional compositions of submicron aerosol species for the entire study. The size distribution of EC was estimated based on that of $\mathrm{m} / \mathrm{z}, 57$ after removing the contribution of $\mathrm{C}_{3} \mathrm{H}_{5} \mathrm{O}^{+}$. significant morning peak due to local traffic influence. While the average $\mathrm{N} / \mathrm{C}$ ratio of $0.012( \pm 0.004)$ is similar to the values observed from previous HR-AMS studies (DeCarlo et al., 2008; Aiken et al., 2009; Sun et al., 2009), periods with much higher N/C ratio $(\sim 0.03-0.04)$ are also observed, likely due to the formation of $\mathrm{N}$-containing organic compounds (Sect. 3.5.4).

\subsection{Chemically-resolved size distributions of submicron aerosol particles}

The average size distributions of aerosol species and the sizeresolved aerosol composition for the entire campaign are shown in Fig. 6. We derived the size distribution of EC based on $\mathrm{m} / z 57$ after removing the contribution of $\mathrm{C}_{3} \mathrm{H}_{5} \mathrm{O}^{+}$ (Fig. 7), assuming that the distribution pattern of $\mathrm{EC}$ mirrors that of $\mathrm{C}_{4} \mathrm{H}_{9}^{+}-$a dominant hydrocarbon ion at $\mathrm{m} / \mathrm{z}$ 57 (Fig. 5c). The rationales behind this assumption are: (1) $\mathrm{C}_{4} \mathrm{H}_{9}^{+}$(or $\mathrm{m} / z, 57$ of the unit resolution AMS data) is an AMS spectral tracer for HOA (Canagaratna et al., 2004; Zhang et al., 2005a; Aiken et al., 2008) and (2) HOA is a surrogate for combustion-related POA in urban areas (Zhang et al., 2005c, 2007a; Jimenez et al., 2009; Ulbrich et al., 2009; Allan et al., 2010; $\mathrm{Ng}$ et al., 2010). Indeed, $\mathrm{C}_{4} \mathrm{H}_{9}^{+}$correlates well with $\mathrm{EC}\left(r^{2}=0.42\right)$ and $\mathrm{NO}_{\mathrm{x}}\left(r^{2}=0.61\right)$. The assumption is also supported by the similar size distributions between $\mathrm{m} / \mathrm{z} 57$ and BC from the SP-AMS measurements of exhaust plumes of heavy duty trucks and Metropolitan Transportation Authority (MTA) standard buses during this campaign (Massoli et al., 2010). However, since $\mathrm{C}_{3} \mathrm{H}_{5} \mathrm{O}^{+}$ 

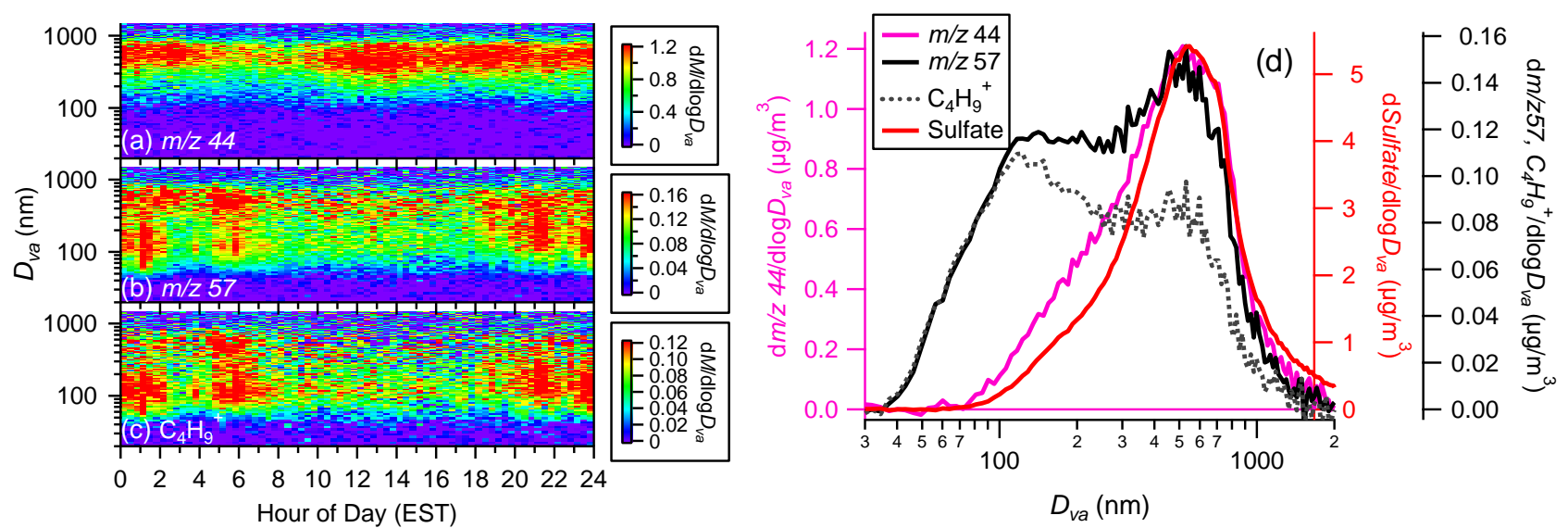

Fig. 7. Diurnal evolution of the size distributions of (a) $m / z, 44$, (b) $m / z, 57$, and (c) $\mathrm{C}_{4} \mathrm{H}_{9}^{+}$. (d) The average size distributions of $m / z$, $57, m / z$ $44, \mathrm{C}_{4} \mathrm{H}_{9}^{+}$, and sulfate for entire study.

contributes $\sim 30 \%$ of the $\mathrm{m} / \mathrm{z}, 57$ signal during this study, the size distributions of $\mathrm{m} / \mathrm{z} 57$ may be influenced by oxygenated species that are secondary in origin. The poor correlation between $\mathrm{C}_{3} \mathrm{H}_{5} \mathrm{O}^{+}$and $\mathrm{C}_{4} \mathrm{H}_{9}^{+}\left(r^{2}=0.14\right)$ indicates their differences in sources. Similarly, Liggio et al. (2010) observed at a rural site of Ontario, Canada that the ratios of $\mathrm{C}_{3} \mathrm{H}_{5} \mathrm{O}^{+}$ to $\mathrm{C}_{4} \mathrm{H}_{9}^{+}$in aerosols increased with the photochemical age, suggesting the association of $\mathrm{C}_{3} \mathrm{H}_{5} \mathrm{O}^{+}$with $\mathrm{SOA}$ or oxidized POA.

We estimated the size distribution of $\mathrm{C}_{3} \mathrm{H}_{5} \mathrm{O}^{+}$according to that of $m / z 44$, which is an AMS spectral tracer for OOA (Zhang et al., 2005a). $\mathrm{C}_{3} \mathrm{H}_{5} \mathrm{O}^{+}$correlates well with $\mathrm{m} / \mathrm{z} 44$ $\left(r^{2}=0.73\right)$ and moderately with sulfate $\left(r^{2}=0.29\right)$, a wellknown secondary inorganic aerosol species. The size distributions of $m / z 44$ and sulfate also closely resemble each other (Figs. 7 and 3c). Note that upon these treatments, the accumulation mode of EC may nevertheless be overestimated because of the contribution of OOA to $\mathrm{C}_{4} \mathrm{H}_{9}^{+}(\sim 10 \%$ of the total $\mathrm{C}_{4} \mathrm{H}_{9}^{+}$signals on average, Sect. 3.5.2), especially in late afternoon when SOA production is intense. A support for this possibility is the better correlation of $\mathrm{C}_{4} \mathrm{H}_{9}^{+}$with $\mathrm{EC}$ $\left(r^{2}=0.60\right)$ and $\mathrm{NO}_{\mathrm{x}}\left(r^{2}=0.76\right)$ during morning rush hours (04:00-08:00 a.m., EST or 05:00-09:00 am local time) than other times of day.

All aerosol species show an overlapping accumulation mode peaking at $\sim 550 \mathrm{~nm}$ in vacuum aerodynamic diameter $\left(D_{\text {va }}\right)$ (Fig. 6a). This mode dominates the size distributions of secondary aerosol species, i.e., sulfate, nitrate and ammonium, and $\mathrm{m} / \mathrm{z}, 44$ as well. In addition, it usually persists throughout the day with relatively little variations in intensity (Fig. 3). However, a mode peaking at $100-150 \mathrm{~nm}$ shows up in the size distributions of organics, EC (Fig. 6), and $\mathrm{m} / \mathrm{z}$ 57 (Fig. 7b), suggesting that primary carbonaceous particles are externally mixed with secondary species. Similar phenomena were observed at various other urban sites (Allan et al., 2003a; Alfarra et al., 2004; Drewnick et al., 2004b;
McFiggans et al., 2005; Zhang et al., 2005b; Takegawa et al., 2006; Weimer et al., 2006; Huang et al., 2010; Sun et al., 2010) and in a chamber study on mixing and partitioning of semi-volatile SOA and POA related to vehicle emission (Asa-Awuku et al., 2009).

During this study, ultrafine particles $(<100 \mathrm{~nm})$ are almost completely composed of carbonaceous material with EC contributing $24 \%$ of total mass and OA contributing an average $73 \%$. EC is only a minor mass fraction $(<5 \%)$ of particles larger than $200 \mathrm{~nm}$. The accumulation mode aerosols are mainly composed of organics and sulfate, which together account for $\sim 80 \%$ of the total mass.

\subsection{Determination of OA components and characterization of their sources and processes}

PMF analysis of the HRMS of OA identified five OA components, each of which demonstrates distinct temporary variation and mass spectral patterns (Fig. 8) that are indicative of their associations with unique sources and processes. In brief, the OA components include: (1) a highly oxidized and low-volatility OOA (LV-OOA; O/C =0.63), (2) a less oxidized and semi-volatile OOA (SV-OOA; O/C =0.38), (3) a nitrogen-enriched $\mathrm{OA}(\mathrm{NOA})$ with a much higher $\mathrm{N} / \mathrm{C}$ ratio (0.0523) than other OA components $(\sim 0.004-0.011)$, (4) a cooking-emission related OA (COA) which shows spectral features similar to those of POA from cooking emissions and a unique diurnal pattern peaking during lunch and dinner times, and (5) a hydrocarbon-like OA component (HOA) that represents POA from incomplete fossil fuel combustion given its low $\mathrm{O} / \mathrm{C}$ ratio $(0.06)$ and good correlation with combustion emission tracers such as $\mathrm{NO}_{\mathrm{x}}$ and EC. Detailed discussions on each component, including the mass spectral profiles, correlations with the tracer species, temporal variation patterns, and associations with different sources and processes, are given in the following subsections. 

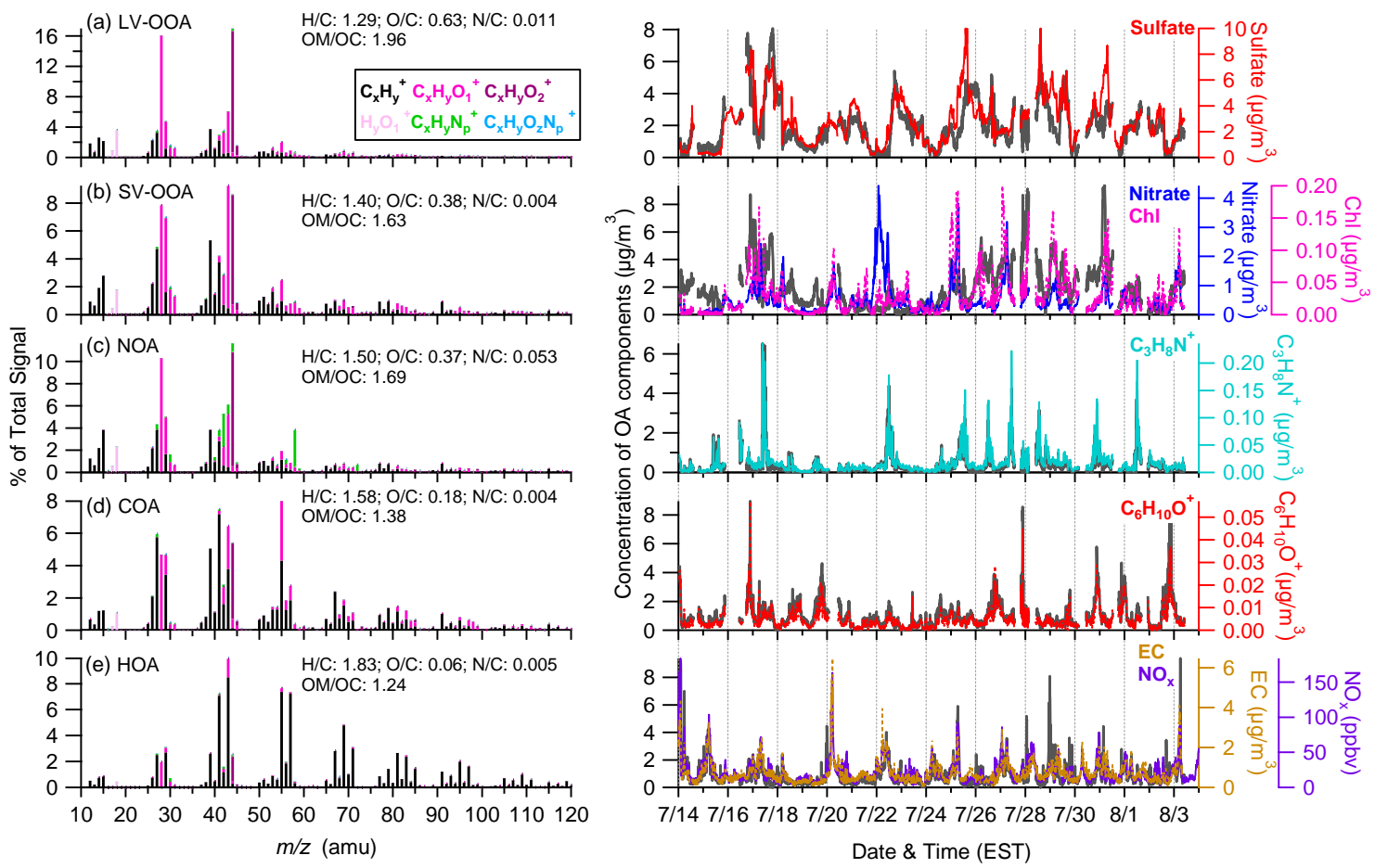

Fig. 8. HRMS (left) and time series (right) of OA components: (a) low-volatility oxygenated OA (LV-OOA) (b) semi-volatile OOA (SVOOA), (c) nitrogen-enriched OA (NOA), (d) cooking-emission OA (COA), and (e) hydrocarbon-like OA (HOA). Also shown are the corresponding time trends of tracer compounds, i.e., sulfate for regional secondary species in (a),nitrate and chloride for semi-volatile secondary species in (b), $\mathrm{C}_{3} \mathrm{H}_{8} \mathrm{~N}^{+}$as a tracer ion for amine-type of compounds in (c), $\mathrm{C}_{6} \mathrm{H}_{10} \mathrm{O}^{+}$as a tracer ion for cooking aerosols in (d), and $\mathrm{EC}$ and $\mathrm{NO}_{\mathrm{x}}$ as tracers for combustion emissions in (e). The elemental ratios and OM/OC ratio of each component are also shown in the legends.

\subsubsection{Semi-volatile and low-volatility OOA (SV-OOA \& LV-OOA)}

The mass spectrum of LV-OOA (Fig. 8a) is characterized by a dominant peak at $m / z 44\left(\mathrm{CO}_{2}^{+}\right)$, similar to the more oxidized OOA-1 component determined at other urban sites (Lanz et al., 2007; Ulbrich et al., 2009; Sun et al., 2010). Its $\mathrm{O} / \mathrm{C}$ and $\mathrm{OM} / \mathrm{OC}$ ratios (0.63 and 1.96 , respectively) are in the range of the values of LV-OOA and total OOA (when LV- and SV-OOA are not separated) observed worldwide (Jimenez et al., 2009; Ng et al., 2010). The mass spectrum of SV-OOA (Fig. 8b), which has lower O/C ratio (0.38) and higher fraction of $m / z, 43\left(f_{43}=9.3 \%\right.$, mainly $\mathrm{C}_{2} \mathrm{H}_{3} \mathrm{O}^{+}$) compared to LV-OOA, tracks the spectral pattern of previously reported SV-OOA (Morgan et al., 2010; $\mathrm{Ng}$ et al., 2010). In addition, the spectrum of SV-OOA resembles those of biogenic SOA observed in ambient atmosphere (Chen et al., 2009; Slowik et al., 2010) and chamber experiments (Kiendler-Scharr et al., 2009; Shilling et al., 2009; Chhabra et al., 2010).

A survey of the correlations between the five OA components and individual ions in the HRMS is shown in Fig. 9. LV-OOA shows most significant correlation with oxygenated ions containing two $\mathrm{O}$ atoms $\left(\mathrm{C}_{\mathrm{x}} \mathrm{H}_{\mathrm{y}} \mathrm{O}_{2}^{+}\right)$followed by $\mathrm{C}_{\mathrm{x}} \mathrm{H}_{\mathrm{y}} \mathrm{O}_{1}^{+}$, and very weak correlation with $\mathrm{C}_{\mathrm{x}} \mathrm{H}_{\mathrm{y}}^{+}$ and $\mathrm{C}_{\mathrm{x}} \mathrm{H}_{\mathrm{y}} \mathrm{N}_{\mathrm{p}}^{+}$. On average LV-OOA accounts for $51 \%$ and $38 \%$ of $\mathrm{C}_{\mathrm{x}} \mathrm{H}_{\mathrm{y}} \mathrm{O}_{2}^{+}$and $\mathrm{C}_{\mathrm{x}} \mathrm{H}_{\mathrm{y}} \mathrm{O}_{1}^{+}$, respectively, for the entire study (Fig. 10). Apportionment of the ions of six major $\mathrm{m} / \mathrm{z}^{\prime}$ 's (Fig. 11) further reveals that that LV-OOA accounts for $53 \%$ of $\mathrm{CO}_{2}^{+}(\mathrm{m} / \mathrm{z}, 44), 61 \%$ of $\mathrm{C}_{2} \mathrm{H}_{2} \mathrm{O}_{2}^{+}(\mathrm{m} / \mathrm{z}, 58)$, and $46 \%$ of $\mathrm{C}_{2} \mathrm{H}_{4} \mathrm{O}_{2}^{+}(\mathrm{m} / \mathrm{z} 60)$. Compared to LV-OOA, SV-OOA shows even tighter correlations with $\mathrm{C}_{\mathrm{x}} \mathrm{H}_{\mathrm{y}} \mathrm{O}_{1}^{+}$and slightly less, yet still high, correlations with $\mathrm{C}_{\mathrm{x}} \mathrm{H}_{\mathrm{y}} \mathrm{O}_{2}^{+}$. It also correlates much better with $\mathrm{C}_{\mathrm{x}} \mathrm{H}_{\mathrm{y}}^{+}$ions than $\mathrm{LV}$-OOA does. On average, $\mathrm{SV}$-OOA contributes $42 \%$ of the $\mathrm{C}_{\mathrm{x}} \mathrm{H}_{\mathrm{y}} \mathrm{O}_{1}^{+}$signal and $31 \%$ of the $\mathrm{C}_{\mathrm{x}} \mathrm{H}_{\mathrm{y}} \mathrm{O}_{2}^{+}$(Fig. 10). These results clearly indicate that the chemical compositions of the two OOA types are significantly different: SV-OOA comprises less oxygenated, possibly freshly oxidized species, while LV-OOA comprises highly oxidized species including di- and poly-carboxylic acids.

LV-OOA correlates well with sulfate $\left(r^{2}=0.66\right.$, Fig. 8a and Table 2), consistent with previous studies at various sites showing that these two species are secondary in nature and mostly driven by regional production (Zhang et al., 2005c; Lanz et al., 2007; Ulbrich et al., 2009; Sun et al., 2010). SV-OOA in general correlates with chloride and nitrate (Fig. 8b), indicating its semi-volatile characteristics (Lanz et al., 2007; Ulbrich et al., 2009; Sun et al., 2010). The 


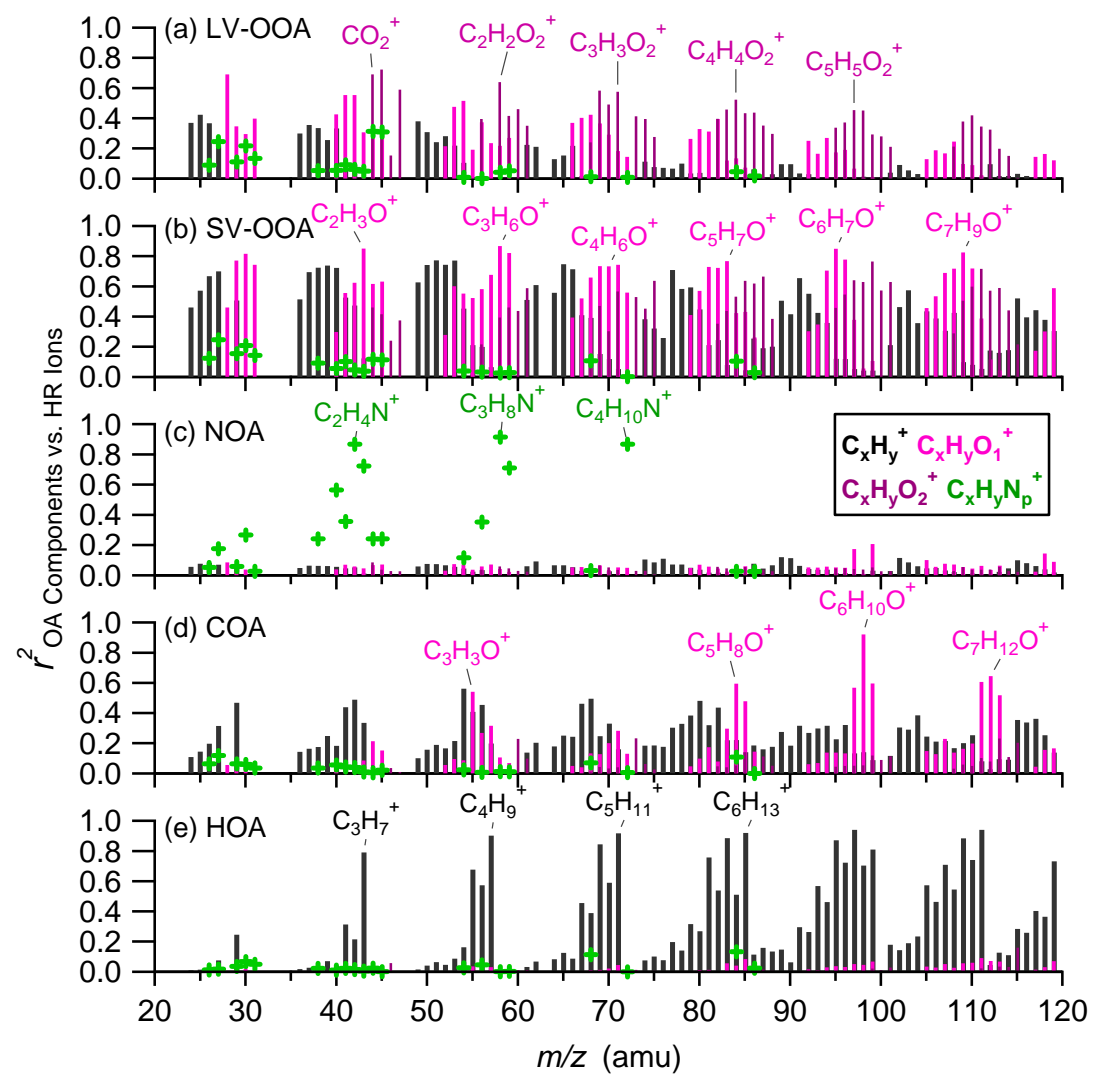

Fig. 9. Correlations of each OA component with the HRMS ions colored by four ion categories, i.e., $\mathrm{C}_{x} \mathrm{H}_{y}^{+}, \mathrm{C}_{\mathrm{x}} \mathrm{H}_{\mathrm{y}} \mathrm{O}_{1}^{+}, \mathrm{C}_{\mathrm{x}} \mathrm{H}_{\mathrm{y}} \mathrm{O}_{2}^{+}$, and $\mathrm{C}_{\mathrm{x}} \mathrm{H}_{\mathrm{y}} \mathrm{N}_{\mathrm{p}}^{+}$. The formulas of the ions that show significant correlations with individual OA components are marked.

Table 2. Correlations between OA components and tracers from collocated measurements.

\begin{tabular}{lrrlll}
\hline & $r^{2}$ & Slope & & $r^{2}$ & Slope \\
\hline HOA vs. EC & 0.44 & $1.29^{\mathrm{a}}$ & SV-OOA vs. Chloride & 0.30 & $48.9^{\mathrm{a}}$ \\
& 0.72 & $1.41^{\mathrm{b}}$ & Total OOA vs. Sulfate & 0.51 & $1.29^{\mathrm{a}}$ \\
& 0.65 & $1.25^{\mathrm{c}}$ & & 0.74 & $0.38^{\mathrm{b}}$ \\
& 0.59 & $0.045^{\mathrm{a}}$ & Total OOA vs. $\mathrm{O}_{\mathrm{x}}$ & 0.08 & $0.11^{\mathrm{a}}$ \\
HOA vs. $\mathrm{NO}_{\mathrm{x}}$ & 0.82 & $0.042^{\mathrm{b}}$ & & 0.55 & $0.12^{\mathrm{d}}$ \\
& 0.66 & $0.65^{\mathrm{a}}$ & & & \\
\hline
\end{tabular}

a NYC, This study.

b Pittsburgh Zhang et al. (2005c).

${ }^{c}$ BC, Mexico City Aiken et al. (2009).

d Mexico City Aiken et al. (2009).

correlation coefficient between SV-OOA and nitrate appears low $\left(r^{2}=0.05\right)$, mainly due to the occurrence of several nighttime nitrate plumes (e.g., 22 July) likely from nocturnal processing of $\mathrm{N}_{2} \mathrm{O}_{5}$. For instance, upon excluding the nitrate plume on July 22 (5\% of total data points), the correlation between SV-OOA and nitrate improves to $r^{2}=0.17$. In comparison to the tight correlation between LV-OOA and sulfate, the relatively weaker correlation between SV-OOA and chloride/nitrate might also be due to the contribution of biogenic $\mathrm{OA}$ to SV-OOA in summer. Total, OOA (=LV-OOA + SV-
OOA) correlates well with total secondary inorganic species (=sulfate + nitrate + chloride, $r^{2}=0.50$, Fig. 12a), marking the link between OOA and SOA. The ratio of total OOA to sulfate in NYC is 1.29 (Table 2), much higher than 0.38 observed in Pittsburgh (Zhang et al., 2005c), highlighting the importance of SOA contribution to fine PM loading in NYC. Total OOA does not show much correlation with $\mathrm{O}_{\mathrm{x}}$ $\left(=\mathrm{O}_{3}+\mathrm{NO}_{2}, r^{2}=0.08\right)$, similar to the observations made in Pittsburgh (Zhang et al., 2005c). 

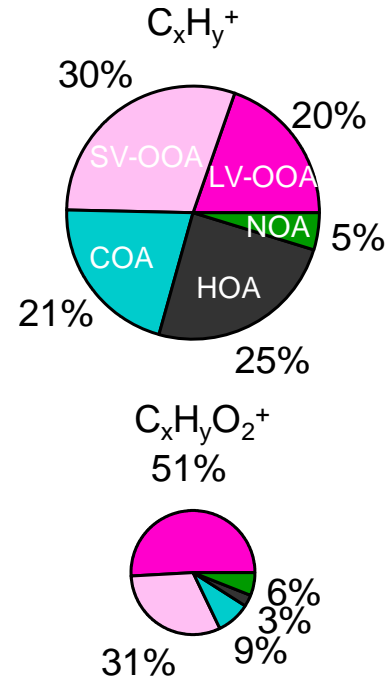

Fig. 10. Average contribution of OA components to four ions categories, i.e., $\mathrm{C}_{\mathrm{x}} \mathrm{H}_{\mathrm{y}}^{+}, \mathrm{C}_{\mathrm{x}} \mathrm{H}_{\mathrm{y}} \mathrm{O}_{1}^{+}, \mathrm{C}_{\mathrm{x}} \mathrm{H}_{\mathrm{y}} \mathrm{O}_{2}^{+}$, and $\mathrm{C}_{\mathrm{x}} \mathrm{H}_{\mathrm{y}} \mathrm{N}_{\mathrm{p}}^{+}$, for the entire study. The area of each pie is scaled to be proportional to the mass concentration of the corresponding category.

LV-OOA accounts for $30.3 \%$ of the OA mass on average, with the average contribution up to $46 \%$ during late afternoon and down to $22 \%$ at night (Fig. 13). SV-OOA accounts for an average $34 \%$ of the OA mass, showing a major contribution $(\sim 50 \%)$ in early morning. LV-OOA and SV-OOA together account for $64 \%$ of OA on average, similar to the estimated SOA contribution (63-73\%) in NYC using the EC tracer method (Rattigan et al., 2010). In addition, OOA in total accounts for $81 \%$ of the $\mathrm{O}$ mass, $58 \%$ of the $\mathrm{C}$ mass, $52 \%$ of the $\mathrm{H}$ mass, and $49 \%$ of the $\mathrm{N}$ mass in OA (Fig. S6).

LV-OOA displays a pronounced diurnal cycle that is characterized by a gradual increase in concentration from $\sim 09: 00$ a.m. to $\sim 17: 00$ p.m. (Fig. 13a). SV-OOA also starts to increase at $\sim$ 09:00 a.m. but peaks at $\sim 13: 00 \mathrm{p} . \mathrm{m}$. The decrease of SV-OOA in the afternoon is likely due to higher ambient temperature that evaporates more semi-volatile species and the rising boundary layer, counteracting the photochemical production of SOA. Since the decrease of SV-OOA is accompanied with a gradual increase of LV-OOA, it is also possible that further oxidation of less oxidized, more-volatile species to highly oxidized, less-volatile species has occurred. Indeed, the $\mathrm{O} / \mathrm{C}$ ratio of total OOA gradually increases from 0.49 to 0.54 between 09:00 a.m. and 17:00 p.m. The continuous oxidation of SV-OOA to LV-OOA was observed at a remote coastal site in Europe as well (Hildebrandt et al., 2010).

\subsubsection{Hydrocarbon-like OA (HOA)}

The mass spectrum of HOA (Fig. 8e), which is characterized with the prominent $\mathrm{C}_{\mathrm{x}} \mathrm{H}_{2 \mathrm{x}-1}^{+}$and $\mathrm{C}_{\mathrm{x}} \mathrm{H}_{2 \mathrm{x}+1}^{+}$ion series, is very similar to previously reported reference spectra of POA emitted from gasoline and diesel combustion sources (Cana- garatna et al., 2004; Schneider et al., 2006) and the spectra of HOA components determined at other sites (Zhang et al., 2005a; Aiken et al., 2009). The O/C (0.06) and OM/OC (1.24) ratios of HOA are also close to the values (0.03-0.04 and 1.22-1.24) determined for POA in motor vehicle exhaust (Mohr et al., 2009). As shown in Fig. 9e, HOA correlates best with hydrocarbon ions $\mathrm{C}_{\mathrm{x}} \mathrm{H}_{2 \mathrm{x}+1}^{+}$and $\mathrm{C}_{\mathrm{x}} \mathrm{H}_{2 \mathrm{x}-1}^{+}$. It contributes $25 \%$ of the $\mathrm{C}_{\mathrm{x}} \mathrm{H}_{\mathrm{y}}^{+}$signal and only $3 \%$ of the $\mathrm{C}_{\mathrm{x}} \mathrm{H}_{\mathrm{y}} \mathrm{O}_{1}^{+}$ and the $\mathrm{C}_{\mathrm{x}} \mathrm{H}_{\mathrm{y}} \mathrm{O}_{2}^{+}$signals (Fig. 10). In addition, HOA correlates well with combustion tracers such as EC $\left(r^{2}=0.44\right)$ and $\mathrm{NO}_{\mathrm{x}}\left(r^{2}=0.59\right)$ (Fig. 8e and Table 2) and presents a pronounced morning peak associated with traffic emissions (Fig. 13a). These facts together indicate that HOA is likely a surrogate for combustion POA, a conclusion achieved in a number of other studies (Zhang et al., 2005a, c; Aiken et al., 2009; Ulbrich et al., 2009). HOA on average accounts for $14.2 \%$ of the total OA mass for the whole campaign, showing the highest contribution $(\sim 28 \%)$ in the morning and the lowest ( 8\%) in the afternoon (Fig. 13b). As summarized in Table 2, the average ratios of HOA/EC (1.29) and HOA/NO $\left(0.045 \mu \mathrm{g} \mathrm{m}^{-3} \mathrm{ppbv}^{-1}\right)$ observed in this study are similar to the values reported for Pittsburgh (Zhang et al., 2005c) and Mexico City (Aiken et al., 2009).

\subsubsection{Cooking OA (COA)}

Although emissions related to cooking activities have been observed to contribute a significant fraction $(\sim 5-20 \%)$ of OA at various urban sites (Rogge et al., 1991; Zheng et al., 2002; Chow et al., 2007), reports of COA from AMS measurements are rare (Allan et al., 2010; Huang et al., 2010). In this study, a COA component was identified. The HRMS spectrum of COA is significantly different from those of other OA components but very similar to the reference spectra of POA from cooking emissions (Mohr et al., 2009) as well as the spectra of COA components observed in London (Allan et al., 2010) and Beijing (Huang et al., 2010).

The COA spectrum is characterized by a high ratio of $\mathrm{m} / \mathrm{z}$ $55 / 57(=2.9)$ and a high fraction of $m / z 55\left(f_{55}=8 \%\right)$, which could be used as a diagnostic indicator for the presence of COA at urban locations. As shown in Fig. 11, both $\mathrm{m} / \mathrm{z} 55$ and 57 have significant contributions from COA, especially their oxygenated ions. In specific, COA contributes $38 \%$ and $29 \%$, respectively, of $\mathrm{C}_{3} \mathrm{H}_{3} \mathrm{O}^{+}$and $\mathrm{C}_{4} \mathrm{H}_{7}^{+}$at $\mathrm{m} / 2.55$ and $25 \%$ and $20 \%$, respectively, of $\mathrm{C}_{3} \mathrm{H}_{5} \mathrm{O}^{+}$and $\mathrm{C}_{4} \mathrm{H}_{9}^{+}$at $\mathrm{m} / z$ 57. In addition, $\mathrm{COA}$ shows most significant correlation with a few $\mathrm{C}_{\mathrm{x}} \mathrm{H}_{\mathrm{y}} \mathrm{O}_{1}^{+}$ions (e.g., $\mathrm{C}_{5} \mathrm{H}_{8} \mathrm{O}^{+}, \mathrm{C}_{6} \mathrm{H}_{10} \mathrm{O}^{+}$, and $\mathrm{C}_{7} \mathrm{H}_{12} \mathrm{O}^{+}$in Fig. 9d), all of which are prominent peaks in the sources spectra of cooking emissions, thus could be used as spectral markers for COA.

The HRMS of COA reveals that it is on average more oxidized than $\mathrm{HOA}(\mathrm{O} / \mathrm{C}=0.18$ vs. 0.06$)$, containing much higher contribution of oxygenated ions $\mathrm{C}_{\mathrm{x}} \mathrm{H}_{\mathrm{y}} \mathrm{O}_{1}^{+}$ and $\mathrm{C}_{\mathrm{x}} \mathrm{H}_{\mathrm{y}} \mathrm{O}_{2}^{+}$(30\% vs. $\left.\sim 9 \%\right)$, thus higher $\mathrm{O}$ content mass 

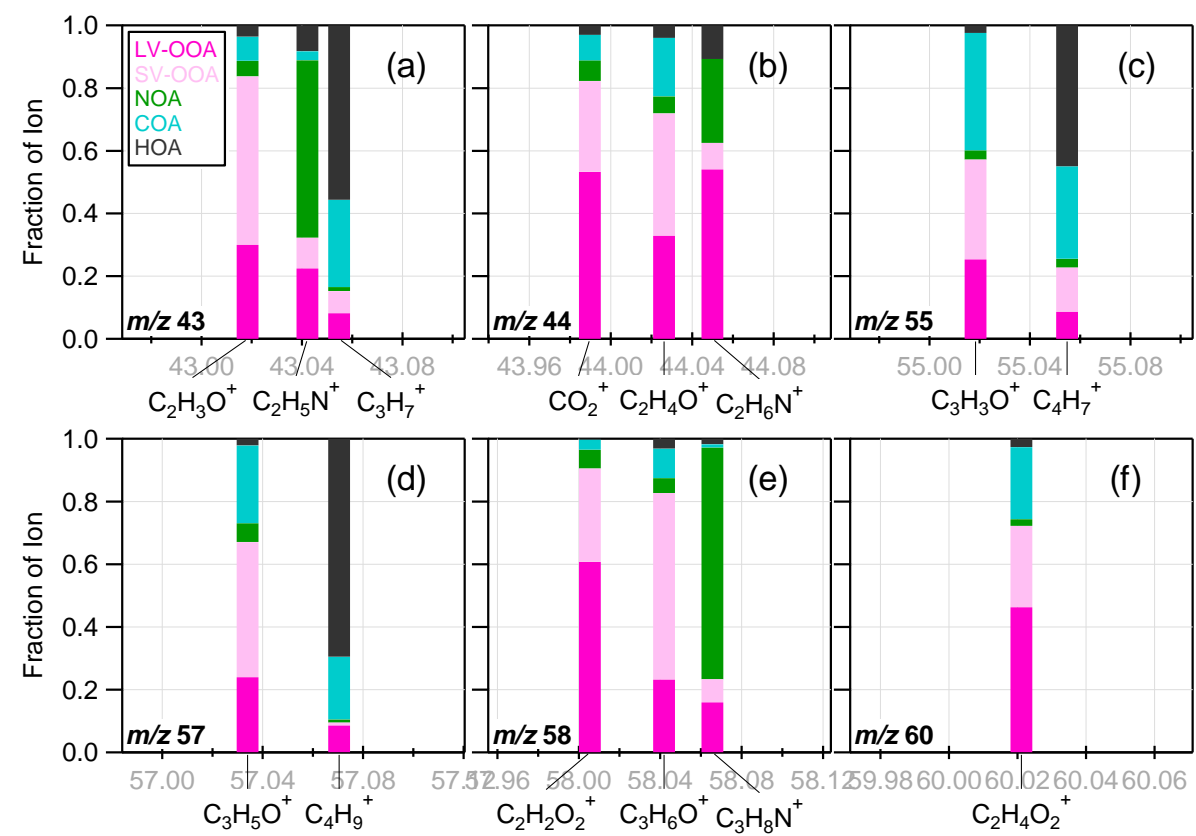

Fig. 11. Average contribution of each OA component to the ions at $m / z$, (a) 43 , (b) 44 , (c) 55 , (d) 57 , (e) 58 , and (f) 60 . Note that only the major ions at each $m / z$ are shown.
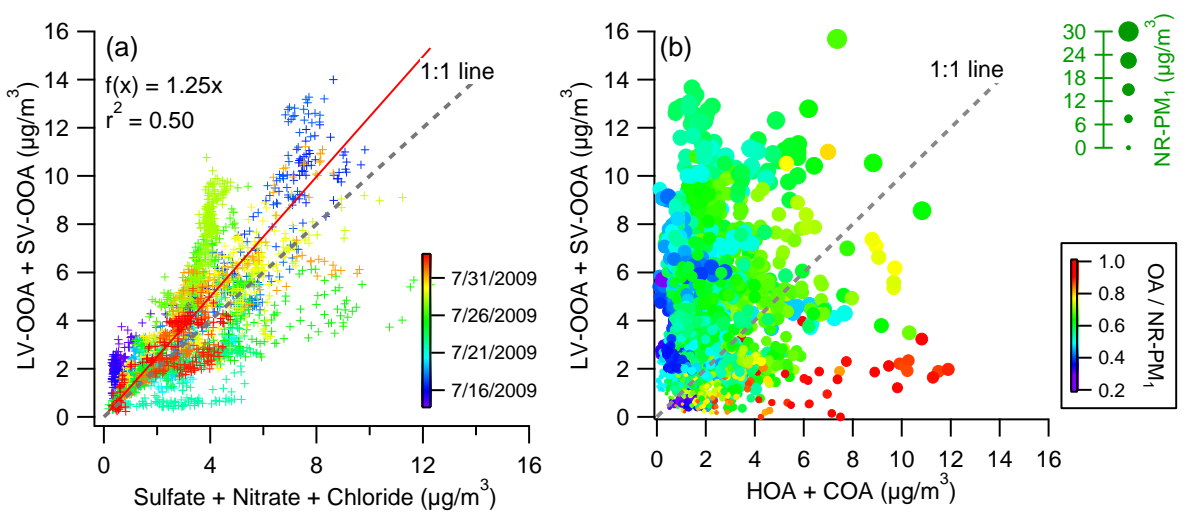

Fig. 12. Correlations of (a) total OOA (=LV-OOA + SV-OOA $)$ vs. total secondary inorganic anions (=Sulfate + Nitrate + Chloride $)$. The data fitting was performed using the orthogonal distance regression (ODR), and (b) total OOA vs. POA (=HOA + COA), colored by the mass fraction of OA in NR-PM . The marker size is proportional to the concentration of total NR-PM $_{1}$.
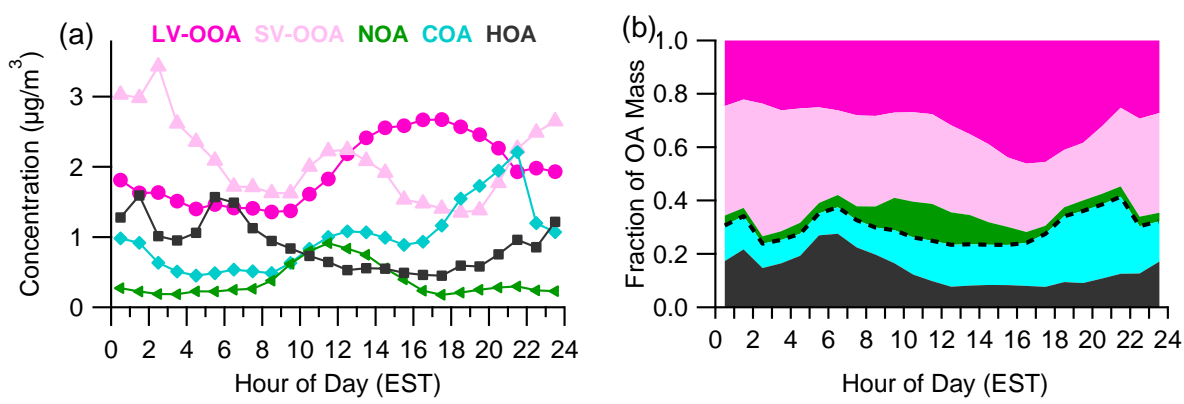

Fig. 13. Diurnal cycles of (a) mass concentrations and (b) mass fractions of five OA components. The dash line in (b) shows the mass fraction of POA (HOA + COA). 
(10\% vs. 3\%), consistent with the detection of more oxygenated organic species in meat cooking emissions (Mohr et al., 2009). The $\mathrm{O} / \mathrm{C}$ and $\mathrm{H} / \mathrm{C}$ ratios of $\mathrm{COA}$ are 0.18 and 1.58 , respectively (Fig. 8d). The diurnal cycle of COA shows distinctive peaks corresponding to lunch and dinner times. Similar diurnal patterns of COA were observed in London (Allan et al., 2010) and Beijing (Huang et al., 2010). On average, COA accounts for $16 \%$ of the total OA mass in NYC. Similar fractions of cooking aerosol were determined using the molecular tracer approach in Los Angeles (Rogge et al., 1991), Fresno, CA (Chow et al., 2007), and some urban sites in the southeastern US (Zheng et al., 2002).

During this study, POA $(=\mathrm{HOA}+\mathrm{COA})$ accounts for an average $30 \%$ of the OA mass and up to $\sim 40 \%$ during morning rush hour and at night (Fig. 13b). It is interesting to note that despite the fact that our sampling site is close to two major highways $(<1$ mile), the average mass concentration of COA $\left(1.02 \mu \mathrm{g} \mathrm{m}^{-3}\right)$ is higher than that of HOA $\left(0.91 \mu \mathrm{g} \mathrm{m}^{-3}\right)$. This is an indication that cooking activities are a significant source of primary particles in NYC and that efforts to reduce particle pollution in this densely populated metropolitan area should focus on controlling both cooking and traffic emissions. POA and total OOA show almost no correlation $\left(r^{2}=0.01\right.$, Fig. 12b), confirming their different source origins. However, there is a general trend that low particle loading periods are characterized with elevated POA that accounts for a high mass fraction of OA (Fig. 12b), due to stronger influences from local primary emissions. High PM events, on the other hand, are mainly contributed by secondary inorganic species and oxygenated organics species formed regionally.

\subsubsection{Nitrogen-enriched OA (NOA)}

A unique $\mathrm{N}$-enriched $\mathrm{OA}$ (NOA) component was determined for this study. Compared to the other four OA components, it shows a much higher N/C ratio (0.053; Fig. 8c) and correlates much better with the $\mathrm{N}$-containing ions (Fig. 9c). The NOA component correlates particularly tight $\left(\mathrm{r}^{2}>0.85\right)$ with $\mathrm{C}_{2} \mathrm{H}_{4} \mathrm{~N}^{+}, \mathrm{C}_{3} \mathrm{H}_{8} \mathrm{~N}^{+}$, and $\mathrm{C}_{4} \mathrm{H}_{10} \mathrm{~N}^{+}$, which were likely generated from amino compounds (McLafferty and Turecek, 1993). It, however, shows almost no correlation with $\mathrm{C}_{\mathrm{x}} \mathrm{H}_{\mathrm{y}}^{+}$ and $\mathrm{C}_{\mathrm{x}} \mathrm{H}_{\mathrm{y}} \mathrm{O}_{z}^{+}$(Fig. 9c). NOA on average accounts for $5.8 \%$ of the total OA mass, yet $39 \%$ of the $\mathrm{C}_{\mathrm{x}} \mathrm{H}_{\mathrm{y}} \mathrm{N}_{\mathrm{p}}^{+}$signal (Fig. 10) and $33 \%$ of the nitrogen mass (Fig. S6). Note that the NOA of this study is clearly different from the "local N-containing reduced OA" (LOA) detected in Mexico City (Aiken et al., 2009), despite similar N/C ratios (0.06 for LOA). Specifically, the mass spectrum of NOA resembles more to that of OOA, while LOA in Mexico City is more similar to HOA and biomass burning OA (BBOA). The $\mathrm{O} / \mathrm{C}$ and $\mathrm{OM} / \mathrm{OC}$ ratios of NOA are 0.37 and 1.69 , respectively, close to those of SV-OOA but much higher than 0.13 and 1.40 , respectively, of LOA in Mexico City.
The diurnal pattern of NOA is marked with a pronounced noon-time peak (Figs. 13a and 8c) in association with southerly wind (Fig. 14a). To investigate the sources and processes of NOA, periods of highest NOA concentrations $(\sim 17 \%$ of time; denoted as Hi-NOA) are compared to the rest of the time (denoted as LoNOA). The average concentration of NOA during Hi-NOA $\left(1.29 \mu^{-3} \mathrm{~m}^{-3}\right)$ is $\sim 6$ times higher than that during Lo-NOA $\left(0.22 \mu \mathrm{g} \mathrm{m}^{-3}\right)$. Note that the average NR-PM 1 composition is very similar between the two types of periods except for a substantially higher fraction of NOA during HiNOA. Based on comparing measured $\mathrm{NH}_{4}^{+}$vs. predicted $\mathrm{NH}_{4}^{+}\left(=18 \times\left(\mathrm{SO}_{4}^{2-} / 48+\mathrm{NO}_{3}^{-} / 62+\mathrm{Cl}^{-} / 35.5\right)\right.$; Zhang et al., 2007b), particles appear to be slightly anion-rich during $\mathrm{Hi}-$ NOA while fully neutralized during Lo-NOA (Fig. 14b), suggesting that NOA might be carrying positive charges. In addition, Fig. 14c illustrates a broader size distribution of $\mathrm{m} / \mathrm{z}$ 58 - the $m / z$ contributed the most by NOA (Fig. 11e) - during Hi-NOA than during Lo-NOA while the size distributions of both $\mathrm{m} / \mathrm{z} 44$ and 57 show essentially no difference. Other

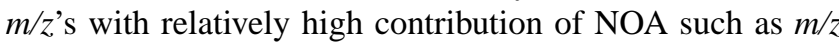
$42\left(\mathrm{C}_{2} \mathrm{H}_{4} \mathrm{~N}^{+}\right)$and $30\left(\mathrm{CH}_{4} \mathrm{~N}^{+}\right)$also show broader size distributions during Hi-NOA. These results together suggest a stronger influence of gas-particle partitioning on the size distribution of NOA, consistent with the hypothesis that NOA is mainly produced via acid-base reactions of amino compounds with acidic gases (Ge et al., 2010b) followed by the condensation of low volatility products onto pre-existing particles. A recent study in Cape Verde observed nonnegligible contribution of aliphatic amines, e.g., dimethylamine $\left(\mathrm{C}_{2} \mathrm{H}_{7} \mathrm{~N}\right)$ and diethylamine $\left(\mathrm{C}_{4} \mathrm{H}_{11} \mathrm{~N}\right)$, to $\mathrm{OC}$ during algal blooms (Müller et al., 2009). Given the proximity of NYC to the Atlantic Ocean, it is possible that the NOA spikes are associated with marine emissions of aliphatic amines. In addition, given that amines are emitted from various industrial operations (Ge et al., 2010a), the large industrial region to the southwest of NYC could also be an important source of NOA.

\subsection{Potential source regions of $\mathrm{PM}_{1}$ in NYC}

Figure 15a and Table S2 present the average composition of $\mathrm{PM}_{1}$ and $\mathrm{OA}$ corresponding to four principal clusters of air masses, i.e., northwest (NW), west (W), southwest (SW), and Atlantic Ocean determined via cluster analysis of the HYSPLIT back-trajectories (BT). The air flow patterns in NYC during this study were predominantly westerly and southwesterly (at frequencies of $37 \%$ and $25 \%$, respectively) with infrequent flows from NW (7.3\%). Aerosol loadings are on average the lowest $\left(6.6 \mu \mathrm{g} \mathrm{m}^{-3}\right)$ for the NW cluster and the highest $\left(14 \mu \mathrm{g} \mathrm{m}^{-3}\right)$ for the SW cluster, consistent with the spatial distribution of emission sources of air pollutants in the northeastern US (Fig. 15a). The correlation of aerosol loadings with different BT clusters is also consistent with the average spatial distribution of AOD determined from satellite 

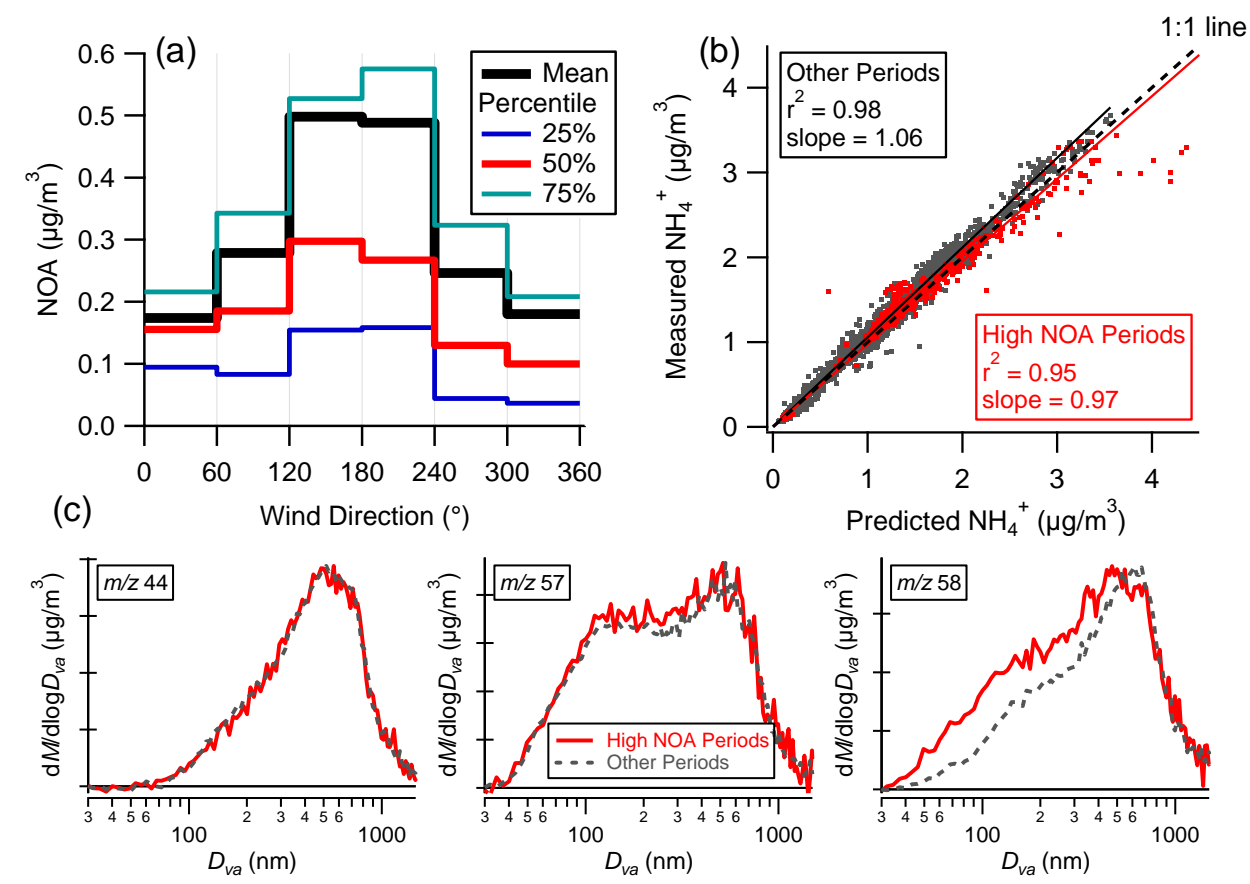

Fig. 14. (a) Statistical distributions of NOA concentrations corresponding to different wind sectors, (b) correlations between measured $\mathrm{NH}_{4}^{+}$ and predicted $\mathrm{NH}_{4}^{+}\left(=\mathrm{SO}_{4}^{2-} / 96 \times 36+\mathrm{NO}_{3}^{-} / 62 \times 18+\mathrm{Cl}^{-} / 35.5 \times 18\right.$; (Zhang et al., 2007b)) , and (c) average size distributions of $m / z$, 44, 57 , and 58 during high NOA periods vs. the rest of the times, respectively. The size distributions in (c) are all scaled to their corresponding maxima for better comparisons of peak shapes.
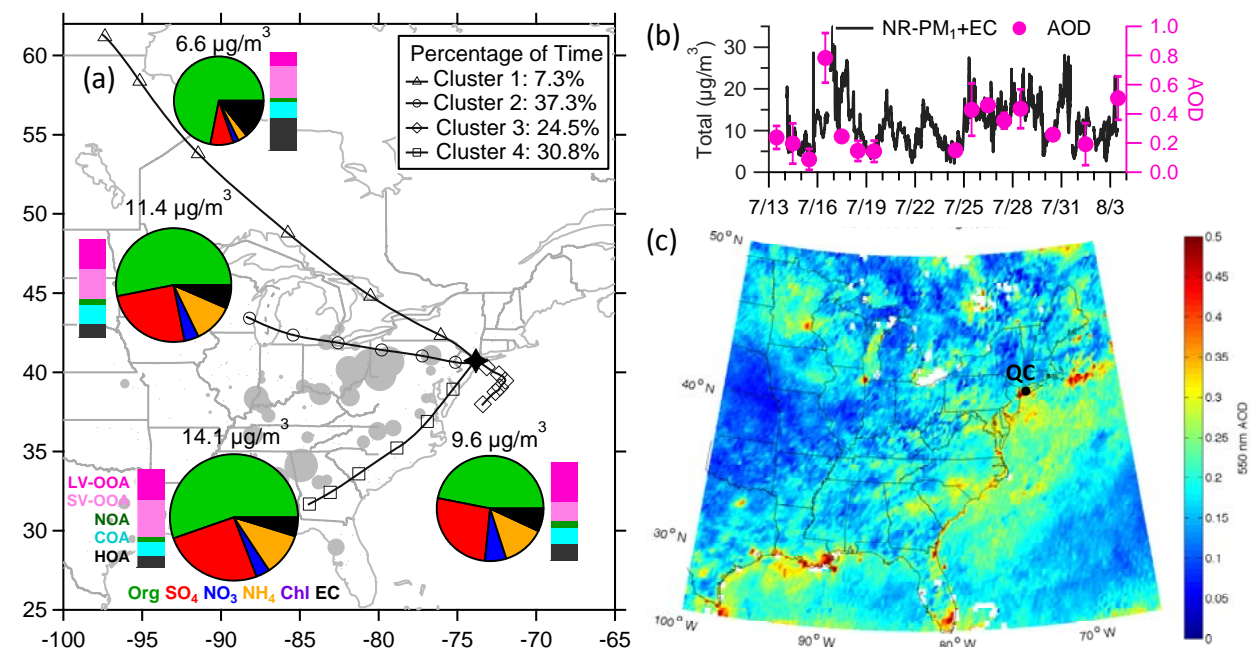

Fig. 15. (a) Average composition of $\mathrm{PM}_{1}$ (pie charts) and $\mathrm{OA}$ (bar charts) for each cluster. The markers on the trajectories indicate $12 \mathrm{~h}$ interval. The area of the pie chart is proportional to the total mass of $\mathrm{PM}_{1}$. The solid grey circles show the distribution of $\mathrm{SO}_{2}$ emission sources from the EPA's National Emission Inventory database (http://www.epa.gov/air/data/netemis.html). Bigger size indicates larger emissions. (b) Time series of total mass of $\mathrm{PM}_{1}$ and AOD retrieved from Terra MODIS at $550 \mathrm{~nm}$ and (c) distribution of average AOD for the entire study.

retrieval. As shown in Fig. 15b, the daily averaged AOD values observed above NYC agree well with the average $\mathrm{PM}_{1}$ concentrations measured during this study, indicating that the satellite AOD data (Fig. 15c) may be a useful indicator for the spatial distribution of $\mathrm{PM}_{1}$ during this study.
The chemical compositions of $\mathrm{PM}_{1}$ are also significantly different among the four clusters, likely reflecting the characteristics of different source regions of air pollutants. For example, the contributions of EC and HOA to $\mathrm{PM}_{1}$ are the highest in the NW cluster, suggesting that emissions of primary 
particles from local sources are a key controller of $\mathrm{PM}_{1}$ concentration and composition in NYC during relatively clean periods. In comparison, secondary species, e.g., OOA and sulfate, dominate the $\mathrm{PM}_{1}$ composition in air masses originated from SW. The westerly air masses also correlate with high aerosol pollution with large fraction of secondary species. The observed correlations between aerosol loading and air mass trajectories are consistent with the high AOD and the large source emissions in the regions $\mathrm{W}$ and SW to NYC, e.g., large coal-fired plants and industrial sources in the Ohio River Valley, West Virginia, and Pennsylvania (Polissar et al., 2001; Qin et al., 2006). In addition, the large contribution of SV-OOA $(\sim 70 \%)$ to total OOA (=SV$\mathrm{OOA}+\mathrm{LV}-\mathrm{OOA}$ ) in the NW cluster (Fig. 15a) might reflect large biogenic emissions in regions to the NW of NYC (Slowik et al., 2010). In addition, for $\sim 25 \%$ of the time during this study, air masses were traced back to the Atlantic Ocean with very low flow speed. Relatively high loadings of $\mathrm{PM}_{1}$ composed of higher fraction of sulfate $\left(26.6 \%\right.$ of $\left.\mathrm{PM}_{1}\right)$ and LV-OOA ( $40 \%$ of OA) appear to correlate with these air masses, which likely reflects the recirculation air pollutions in the US continental outflow. Indeed, the high AOD along the coastal line and near shore (Fig. 15c)seems to support this possibility.

\section{Conclusions}

The mass concentration, chemical composition, and size distributions of submicron aerosol species in NYC were measured in-situ using an HR-AMS in summer 2009. Aerosol composition varies dynamically with $\mathrm{OA}$ and sulfate on average comprising $54 \%$ and $24 \%$ of total $\mathrm{PM}_{1}$ mass. Analysis of aerosol ion balance indicates that submicron particles in NYC are overall bulk neutralized. The size distributions

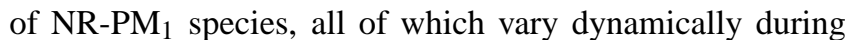
this study, on average present a similar large accumulation mode peaking at $\sim 550 \mathrm{~nm}$ with an additional small mode $(\sim 150 \mathrm{~nm})$ for OA. In addition to boundary layer dynamics, local photochemical production plays an important role in controlling the variation of sulfate and OA during daytime. Gas-to-particle partitioning and nighttime hydrolysis of $\mathrm{N}_{2} \mathrm{O}_{5}$ drive the diurnal cycle of nitrate. The average $\mathrm{O} / \mathrm{C}$ and $\mathrm{OM} / \mathrm{OC}$ ratios of $\mathrm{OA}$ are $0.36( \pm 0.08)$ and $1.62( \pm 0.11)$, respectively.

PMF analysis of the HRMS of OA identifies five components, i.e., a traffic-related HOA, a highly aged, regional LV-OOA, a less oxidized, more volatile SV-OOA, a cookingrelated COA, and a NOA enriched of organic nitrogen compounds. SV-OOA and LV-OOA constitute the largest fraction of OA, accounting for $34 \%$ and $30 \%$, respectively, on average. HOA and COA, which have similar mass concentrations, together account for $30 \%$ of the OA mass. HOA correlates well with the primary traffic emission tracers, with $\mathrm{HOA} / \mathrm{EC}$ and $\mathrm{HOA} / \mathrm{NO}_{\mathrm{x}}$ ratios of 1.29 and 0.045
( $\mu \mathrm{g} \mathrm{m}^{-3} \mathrm{ppbv}^{-1}$ ), respectively. LV-OOA correlates tightly with sulfate and $\mathrm{C}_{\mathrm{x}} \mathrm{H}_{\mathrm{y}} \mathrm{O}_{2}^{+}$ions while SV-OOA correlates better with chloride and the $\mathrm{C}_{\mathrm{x}} \mathrm{H}_{\mathrm{y}} \mathrm{O}_{1}^{+}$ions. The diurnal cycle of HOA shows a pronounced morning traffic peak, so do $\mathrm{EC}$ and $\mathrm{NO}_{\mathrm{x}}$. The diurnal cycles of SV-OOA and LV-OOA demonstrate a trend of chemical evolution of SOA in NYC that likely involves a continuum of oxidation from SV-OOA to LV-OOA. The SV-OOA to LV-OOA evolution is consistent with a gradual increase of $\mathrm{O} / \mathrm{C}$ ratio and a corresponding decrease of $\mathrm{H} / \mathrm{C}$ ratio in total OOA. NOA, which accounts for $5.8 \%$ of the OA mass, yet $33 \%$ of the organic $\mathrm{N}$ mass, shows a pronounced peak around noon time and correlates well with amines related peaks, e.g., $\mathrm{C}_{x} \mathrm{H}_{2 \mathrm{x}+2} \mathrm{~N}^{+}$. Analysis of the sources and ion balance of NOA suggests that $\mathrm{N}$ containing organic species such as amines might have played an important role in the atmospheric processing of OA, likely via acid-base chemistry coupled with photochemical production of acidic organic species. Air mass trajectory analysis, together with satellite AOD observations, indicates that emissions of primary particles from local sources likely play an important role in controlling $\mathrm{PM}_{1}$ concentration and loading in NYC during relatively clean periods associated with northerly flows. High PM pollution events, however, are mainly contributed by secondary inorganic and organic particles typically associated with air masses originated from regions to the west and southwest of the city.

\section{Appendix A}

\section{A1 Estimation of production rates of $\mathrm{HNO}_{3}$ and $\mathrm{H}_{2} \mathrm{SO}_{4}$}

The production rate of $\mathrm{HNO}_{3}$ and $\mathrm{H}_{2} \mathrm{SO}_{4}$ can be estimated from bi-molecule association reactions (Seinfeld and Pandis, 2006). The effective second-order rate constant for a given temperature and pressure (altitude) can be calculated using Eq. (A1).

$$
\begin{aligned}
& \left.k([M], T)=\left(\frac{k_{o}(T)[M]}{1+\frac{k_{o}(T)[M]}{k_{\infty}(T)}}\right) 0.6^{\left\{1+\left[\log \left(\frac{k_{o}(T)[M]}{k_{\infty}(T)}\right)\right]^{2}\right.}\right\}^{-1} \\
& \left(\mathrm{~cm}^{6} \text { molecule }^{-2} \mathrm{~s}^{-1}\right) \\
& k_{o}(T)=k_{o}^{300}\left(\frac{T}{300}\right)^{-n}\left(\mathrm{~cm}^{6} \text { molecule }^{-2} \mathrm{~s}^{-1}\right) \\
& k_{\infty}(T)=k_{\infty}^{300}\left(\frac{T}{300}\right)^{-m}\left(\mathrm{~cm}^{3} \text { molecule }^{-1} \mathrm{~s}^{-1}\right) \\
& \mathrm{NO}_{2}+\mathrm{OH} \stackrel{M}{\longrightarrow} \mathrm{HONO}_{2} \\
& \mathrm{SO}_{2}+\mathrm{OH} \stackrel{M}{\longrightarrow} \mathrm{HOSO}_{2}
\end{aligned}
$$

Where $k_{o}(T)$ (Eq. A2) is low-pressure-limiting rate constant and $k_{\infty}(T)$ is the high-pressure-limiting rate constant. The four parameters $k_{o}^{300}, n, k_{\infty}^{300}$, and $m$ for Reactions (R1 and R2) are listed in Table A1. 
Table A1. Kinetic parameters used to determine the production rates of $\mathrm{HNO}_{3}$ and $\mathrm{H}_{2} \mathrm{SO}_{4}$ (JPL, 2009).

\begin{tabular}{lllll}
\hline & $k_{o}^{300}$ & $n$ & $k_{\infty}^{300}$ & $m$ \\
\hline $\mathrm{NO}_{2}+\mathrm{OH} \stackrel{M}{\longrightarrow} \mathrm{HONO}_{2}$ & $2.0 \times 10^{-30}$ & 3.0 & $2.5 \times 10^{-11}$ & 0 \\
$\mathrm{SO}_{2}+\mathrm{OH} \stackrel{M}{\longrightarrow} \mathrm{HOSO}_{2}$ & $3.0 \times 10^{-31}$ & 3.3 & $1.5 \times 10^{-12}$ & 0 \\
\hline
\end{tabular}

\section{A2 Calculation the equilibrium constant of gas-to- particle partitioning}

Formation of ammonium nitrate involves an equilibrium reaction between the gas phase $\mathrm{NH}_{3}$ and $\mathrm{HNO}_{3}$, and particle phase $\mathrm{NH}_{4} \mathrm{NO}_{3}$ (Reaction R3). The gas-to-particle partitioning is strongly temperature dependent, and the equilibrium constant of Reaction (R3) can be calculated as Eq. (A4) (Seinfeld and Pandis, 2006)

$$
\begin{aligned}
\mathrm{NH}_{3}(\mathrm{~g}) & +\mathrm{HNO}_{3}(\mathrm{~g}) \leftrightarrow \mathrm{NH}_{4} \mathrm{NO}_{3}(\mathrm{~s}) \\
k(T)= & k(298) \exp \left\{a\left(\frac{298}{T}-1\right)\right. \\
& \left.+b\left[1+\ln \left(\frac{298}{T}\right)-\frac{298}{T}\right]\right\}
\end{aligned}
$$

where $T$ is the ambient temperature in Kelvin. $k(298)=$ $3.35 \times 10^{16}\left(\mathrm{~atm}^{-2}\right), a=75.11$, and $b=-13.5$.

\section{Supplementary material related to this article is available online at: http://www.atmos-chem-phys.net/11/1581/2011/ acp-11-1581-2011-supplement.pdf.}

Acknowledgements. This research was supported by the US Department of Energy Office of Science (BER) (grant DEFG02-08ER64627 and DE-SC0002191), New York State Energy Research and Development Authority, New York State Department of Environmental Conservation, and New York State Office of Science, Technology and Academic Research. We acknowledge our Aerodyne colleagues for sharing equipment and useful discussions during the campaign. We thank the New York State Department of Environmental Conservation for use of their facility, and particularly Mike Christopherson, Ed Marion, and Dirk Felton. We thank the Queens College administration and staff, especially Wing Can, for hosting this study. We also thank Douglas Orsini and Kevin Rhoads for assistance with setting up the PILS-IC system.

Edited by: N. M. Donahue

\section{References}

Aiken, A. C., DeCarlo, P. F., Kroll, J. H., Worsnop, D. R., Huffman, J. A., Docherty, K. S., Ulbrich, I. M., Mohr, C., Kimmel, J. R., Sueper, D., Sun, Y., Zhang, Q., Trimborn, A., Northway, M., Ziemann, P. J., Canagaratna, M. R., Onasch, T. B., Alfarra, M. R., Prevot, A. S. H., Dommen, J., Duplissy, J., Metzger, A., Baltensperger, U., and Jimenez, J. L.: O/C and OM/OC ratios of primary, secondary, and ambient organic aerosols with HighResolution Time-of-Flight Aerosol Mass Spectrometry, Environ. Sci. Technol., 42, 4478-4485, 2008.

Aiken, A. C., Salcedo, D., Cubison, M. J., Huffman, J. A., DeCarlo, P. F., Ulbrich, I. M., Docherty, K. S., Sueper, D., Kimmel, J. R., Worsnop, D. R., Trimborn, A., Northway, M., Stone, E. A., Schauer, J. J., Volkamer, R. M., Fortner, E., de Foy, B., Wang, J., Laskin, A., Shutthanandan, V., Zheng, J., Zhang, R., Gaffney, J., Marley, N. A., Paredes-Miranda, G., Arnott, W. P., Molina, L. T., Sosa, G., and Jimenez, J. L.: Mexico City aerosol analysis during MILAGRO using high resolution aerosol mass spectrometry at the urban supersite (T0) - Part 1: Fine particle composition and organic source apportionment, Atmos. Chem. Phys., 9, 66336653, doi:10.5194/acp-9-6633-2009, 2009.

Alfarra, M. R., Coe, H., Allan, J. D., Bower, K. N., Boudries, H., Canagaratna, M. R., Jimenez, J. L., Jayne, J. T., Garforth, A., Li, S.-M., and Worsnop, D. R.: Characterization of urban and regional organic aerosols in the Lower Fraser Valley using two Aerodyne Aerosol Mass Spectrometers, Atmos. Environ., 38, 5745-5758, 2004.

Allan, J. D., Alfarra, M. R., Bower, K. N., Williams, P. I., Gallagher, M. W., Jimenez, J. L., McDonald, A. G., Nemitz, E., Canagaratna, M. R., Jayne, J. T., Coe, H., and Worsnop, D. R.: Quantitative sampling using an Aerodyne Aerosol Mass Spectrometer. Part 2: Measurements of fine particulate chemical composition in two UK Cities, J. Geophys. Res.-Atmos., 108, 4091, doi:4010.1029/2002JD002359, 2003a.

Allan, J. D., Jimenez, J. L., Williams, P. I., Alfarra, M. R., Bower, K. N., Jayne, J. T., Coe, H., and Worsnop, D. R.: Quantitative sampling using an Aerodyne Aerosol Mass Spectrometer. Part 1: Techniques of data interpretation and error analysis, J. Geophys. Res.-Atmos., 108, 4090, doi:4010.1029/2002JD002358, 2003b.

Allan, J. D., Williams, P. I., Morgan, W. T., Martin, C. L., Flynn, M. J., Lee, J., Nemitz, E., Phillips, G. J., Gallagher, M. W., and Coe, H.: Contributions from transport, solid fuel burning and cooking to primary organic aerosols in two UK cities, Atmos. Chem. Phys., 10, 647-668, doi:10.5194/acp-10-647-2010, 2010.

Asa-Awuku, A., Miracolo, M. A., Kroll, J. H., Robinson, A. L., and Donahue, N. M.: Mixing and phase partitioning of primary and secondary organic aerosols, Geophys. Res. Lett., 36, L15827, doi:10.1029/2009g1039301, 2009.

Association, A. L.: State of the Air 2010, American Lung Association, availablea at: http//www.lungusa.org, 2010.

Bae, M.-S., Demerjian, K. L., and Schwab, J. J.: Seasonal estimation of organic mass to organic carbon in $\mathrm{PM}_{2.5}$ at rural and urban locations in New York state, Atmos. Environ., 40, 74677479, 2006.

Brown, S. S., Stark, H., Ryerson, T. B., Williams, E. J., Nicks, D. K., Trainer, M., Fehsenfeld, F. C., and Ravishankara, A. R.: Nitrogen oxides in the nocturnal boundary layer: Simultaneous in situ measurements of $\mathrm{NO}_{3}, \mathrm{~N}_{2} \mathrm{O}_{5}, \mathrm{NO}_{2}, \mathrm{NO}$, and $\mathrm{O}_{3}$, Geophys. Res.-Atmos., 108, 4299, doi:10.1029/2002JD002917, 2003. 
Buset, K. C., Evans, G. J., Richard Leaitch, W., Brook, J. R., and Toom-Sauntry, D.: Use of advanced receptor modelling for analysis of an intensive 5-week aerosol sampling campaign, Atmos. Environ., 40, 482-499, doi:10.1016/j.atmosenv.2005.12.074, 2006.

Canagaratna, M., Jayne, J., Jimenez, J. L., Allan, J. A., Alfarra, R., Zhang, Q., Onasch, T., Drewnick, F., Coe, H., Middlebrook, A., Delia, A., Williams, L., Trimborn, A., Northway, M., Kolb, C., Davidovits, P., and Worsnop, D.: Chase studies of particulate emissions from in-use New York City vehicles, Aerosol Sci. Tech., 38, 555-573, 2004.

Canagaratna, M. R., Jayne, J. T., Ghertner, D. A., Herndon, S., Shi, Q., Jimenez, J. L., Silva, P. J., Williams, P., Lanni, T., Drewnick, F., Demerjian, K. L., Kolb, C. E., and Worsnop, D. R.: Chemical and microphysical characterization of aerosols via Aerosol Mass Spectrometry, Mass Spectrom. Rev., 26, 185-222, 2007.

Chen, Q., Farmer, D. K., Schneider, J., Zorn, S. R., Heald, C. L., Karl, T. G., Guenther, A., Allan, J. D., Robinson, N., Coe, H., Kimmel, J. R., Pauliquevis, T., Borrmann, S., Poschl, U., Andreae, M. O., Artaxo, P., Jimenez, J. L., and Martin, S. T.: Mass spectral characterization of submicron biogenic organic particles in the Amazon Basin, Geophys. Res. Lett., 36, L20806, doi:10.1029/2009g1039880, 2009.

Chhabra, P. S., Flagan, R. C., and Seinfeld, J. H.: Elemental analysis of chamber organic aerosol using an aerodyne high-resolution aerosol mass spectrometer, Atmos. Chem. Phys., 10, 4111-4131, doi:10.5194/acp-10-4111-2010, 2010

Chow, J. C., Watson, J. G., Lowenthal, D. H., Chen, L. W. A., Zielinska, B., Mazzoleni, L. R., and Magliano, K. L.: Evaluation of organic markers for chemical mass balance source apportionment at the Fresno Supersite, Atmos. Chem. Phys., 7, 17411754, doi:10.5194/acp-7-1741-2007, 2007.

Crosier, J., Allan, J. D., Coe, H., Bower, K. N., Formenti, P., and Williams, P. I.: Chemical composition of summertime aerosol in the Po Valley (Italy), northern Adriatic and Black Sea, Q. J. Roy. Meteorol. Soc., 133, 61-75, 2007.

DeCarlo, P. F., Kimmel, J. R., Trimborn, A., Northway, M. J., Jayne, J. T., Aiken, A. C., Gonin, M., Fuhrer, K., Horvath, T., Docherty, K. S., Worsnop, D. R., and Jimenez, J. L.: Field-Deployable, High-Resolution, Time-of-Flight Aerosol Mass Spectrometer, Anal. Chem., 78, 8281-8289, 2006.

DeCarlo, P. F., Dunlea, E. J., Kimmel, J. R., Aiken, A. C., Sueper, D., Crounse, J., Wennberg, P. O., Emmons, L., Shinozuka, Y., Clarke, A., Zhou, J., Tomlinson, J., Collins, D. R., Knapp, D., Weinheimer, A. J., Montzka, D. D., Campos, T., and Jimenez, J. L.: Fast airborne aerosol size and chemistry measurements above Mexico City and Central Mexico during the MILAGRO campaign, Atmos. Chem. Phys., 8, 4027-4048, doi:10.5194/acp8-4027-2008, 2008.

DeCarlo, P. F., Ulbrich, I. M., Crounse, J., de Foy, B., Dunlea, E. J., Aiken, A. C., Knapp, D., Weinheimer, A. J., Campos, T., Wennberg, P. O., and Jimenez, J. L.: Investigation of the sources and processing of organic aerosol over the Central Mexican Plateau from aircraft measurements during MILAGRO, Atmos. Chem. Phys., 10, 5257-5280, doi:10.5194/acp-10-52572010, 2010.

Demerjian, K. L. and Mohnen, V. A.: Synopsis of the temporal variation of particulate matter composition and size, J. Air Waste Manage., 58, 216-233, 2008.
Draxler, R. R. and Rolph, G. D.: HYSPLIT (HYbrid Single-Particle Lagrangian Integrated Trajectory) Model access via NOAA ARL READY Website, available at: http://www.arl.noaa.gov/ready/ hysplit4.html, NOAA Air Resources Laboratory, Silver Spring, MD, 2003.

Drewnick, F., Schwab, J. J., Jayne, J. T., Canagaratna, M., Worsnop, D. R., and Demerjian, K. L.: Intercomparison and evaluation of four semi-continuous $\mathrm{PM}_{2.5}$ sulfate instruments, Atmos. Environ., 37, 3335-3350, 2003.

Drewnick, F., Schwab, J. J., Jayne, J. T., Canagaratna, M., Worsnop, D. R., and Demerjian, K. L.: Measurement of ambient aerosol composition during the PMTACS-NY 2001 using an Aerosol Mass Spectrometer, Part I: Mass concentrations, Aerosol Sci. Tech., 38, 92-103, 2004a.

Drewnick, F., Schwab, J. J., Jayne, J. T., Canagaratna, M., Worsnop, D. R., and Demerjian, K. L.: Measurement of ambient aerosol composition during the PMTACS-NY 2001 using an Aerosol Mass Spectrometer. Part II: Chemically speciated mass distributions, Aerosol Sci. Tech., 38, 104-117, 2004b.

Drewnick, F., Hings, S. S., DeCarlo, P. F., Jayne, J. T., Gonin, M., Fuhrer, K., Weimer, S., Jimenez, J. L., Demerjian, K. L., Borrmann, S., and Worsnop, D. R.: A new Time-of-Flight Aerosol Mass Spectrometer (ToF-AMS) - Instrument description and first field deployment., Aerosol Sci. Tech., 39, 637-658, 2005.

Dutkiewicz, V. A., Qureshi, S., Khan, A. R., Ferraro, V., Schwab, J., Demerjian, K., and Husain, L.: Sources of fine particulate sulfate in New York, Atmos. Environ., 38, 3179-3189, 2004.

Dutkiewicz, V. A., Qureshi, S., Husain, L., Schwab, J. J., and Demerjian, K. L.: Elemental composition of $\mathrm{PM}_{2.5}$ aerosols in Queens, New York: Evaluation of sources of fine-particle mass, Atmos. Environ., 40, 347-359, 2006.

Eatough, D. J., Long, R. W., Modey, W. K., and Eatough, N. L.: Semi-volatile secondary organic aerosol in urban atmospheres: meeting a measurement challenge, Atmos. Environ., 37, 12771292, 2003.

Ge, X., Wexler, A. S., and Clegg, S. L.: Atmospheric Amines - Part I. A review, Atmos. Environ., 45, 524-546, 2011 a.

Ge, X., Wexler, A. S., and Clegg, S. L.: Atmospheric Amines Part II. Thermodynamic properties and gas/particle partitioning, Atmos. Environ., 45, 561-577, 2011b.

Hildebrandt, L., Engelhart, G. J., Mohr, C., Kostenidou, E., Lanz, V. A., Bougiatioti, A., DeCarlo, P. F., Prevot, A. S. H., Baltensperger, U., Mihalopoulos, N., Donahue, N. M., and Pandis, S. N.: Aged organic aerosol in the Eastern Mediterranean: the Finokalia Aerosol Measurement Experiment - 2008, Atmos. Chem. Phys., 10, 4167-4186, doi:10.5194/acp-10-4167-2010, 2010

Hogrefe, O., Schwab, J. J., Drewnick, F., Lala, G. G., Peters, S., Demerjian, K. L., Rhoads, K., Felton, H. D., Rattigan, O. V., Husain, L., and Dutkiewicz, V. A.: Semicontinuous PM2.5 sulfate and nitrate measurements at an urban and a rural location in New York: PMTACS-NY summer 2001 and 2002 campaigns, J. Air Waste Manage., 54, 1040-1060, 2004.

Huang, X.-F., He, L.-Y., Hu, M., Canagaratna, M. R., Sun, Y., Zhang, Q., Zhu, T., Xue, L., Zeng, L.-W., Liu, X.-G., Zhang, Y.-H., Jayne, J. T., Ng, N. L., and Worsnop, D. R.: Highly time-resolved chemical characterization of atmospheric submicron particles during 2008 Beijing Olympic Games using an Aerodyne High-Resolution Aerosol Mass Spectrometer, Atmos. Chem. Phys., 10, 8933-8945, doi:10.5194/acp-10-8933-2010, 
2010.

Huffman, J. A., Jayne, J. T., Drewnick, F., Aiken, A. C., Onasch, T., Worsnop, D. R., and Jimenez, J. L.: Design, modeling, optimization, and experimental tests of a particle beam width probe for the Aerodyne Aerosol Mass Spectrometer, Aerosol Sci. Tech., 39, 1143-1163, 2005.

IPCC: Summary for Policymakers, in: Climate Change 2007: The Physical Science Basis, Contribution of Working Group I to the Fourth Assessment Report of the Intergovernmental Panel on Climate Change, edited by: Solomon, S., Qin, D., Manning, M., Chen, Z., Marquis, M., Averyt, K. B., Tignor M., and Miller H. L., Cambridge University Press, Cambridge, United Kingdom and New York, NY, USA., 2007.

Jayne, J. T., Leard, D. C., Zhang, X., Davidovits, P., Smith, K. A., Kolb, C. E., and Worsnop, D. R.: Development of an aerosol mass spectrometer for size and composition analysis of submicron particles, Aerosol Sci. Tech., 33, 49-70, 2000.

Jimenez, J. L., Jayne, J. T., Shi, Q., Kolb, C. E., Worsnop, D. R., Yourshaw, I., Seinfeld, J. H., Flagan, R. C., Zhang, X., Smith, K. A., Morris, J. W., and Davidovits, P.: Ambient aerosol sampling with an Aerosol Mass Spectrometer, J. Geophys. Res.-Atmos., 108, 8425, doi:8410:1029/2001JD001213, 2003.

Jimenez, J. L., Canagaratna, M. R., Donahue, N. M., Prevot, A. S. H., Zhang, Q., Kroll, J. H., DeCarlo, P. F., Allan, J. D., Coe, H., Ng, N. L., Aiken, A. C., Docherty, K. S., Ulbrich, I. M., Grieshop, A. P., Robinson, A. L., Duplissy, J., Smith, J. D., Wilson, K. R., Lanz, V. A., Hueglin, C., Sun, Y. L., Tian, J., Laaksonen, A., Raatikainen, T., Rautiainen, J., Vaattovaara, P., Ehn, M., Kulmala, M., Tomlinson, J. M., Collins, D. R., Cubison, M. J., E, Dunlea, J., Huffman, J. A., Onasch, T. B., Alfarra, M. R., Williams, P. I., Bower, K., Kondo, Y., Schneider, J., Drewnick, F., Borrmann, S., Weimer, S., Demerjian, K., Salcedo, D., Cottrell, L., Griffin, R., Takami, A., Miyoshi, T., Hatakeyama, S., Shimono, A., Sun, J. Y., Zhang, Y. M., Dzepina, K., Kimmel, J. R., Sueper, D., Jayne, J. T., Herndon, S. C., Trimborn, A. M., Williams, L. R., Wood, E. C., Middlebrook, A. M., Kolb, C. E., Baltensperger, U., and Worsnop, D. R.: Evolution of organic aerosols in the atmosphere, Science, 326, 1525-1529, doi:10.1126/science.1180353, 2009.

JPL: Chemical Kinetics and Photochemical Data for Use in Atmospheric Studies Evaluation Number 16, Jet Propulsion Laboratory, Pasadena, CA, 2009.

Kanakidou, M., Seinfeld, J. H., Pandis, S. N., Barnes, I., Dentener, F. J., Facchini, M. C., Van Dingenen, R., Ervens, B., Nenes, A., Nielsen, C. J., Swietlicki, E., Putaud, J. P., Balkanski, Y., Fuzzi, S., Horth, J., Moortgat, G. K., Winterhalter, R., Myhre, C. E. L., Tsigaridis, K., Vignati, E., Stephanou, E. G., and Wilson, J.: Organic aerosol and global climate modelling: a review, Atmos. Chem. Phys., 5, 1053-1123, doi:10.5194/acp-5-1053-2005, 2005.

Kiendler-Scharr, A., Zhang, Q., Hohaus, T., Kleist, E., Mensah, A., Mentel, T., Spindler, C., Uerlings, R., Tillmann, R., and Wildt, J.: Aerosol Mass Spectrometric Features of Biogenic SOA: Observations from a Plant Chamber and in a Rural Atmospheric Environment, Environ. Sci. Technol., 43, 8166-8172, 2009.

Kleinman, L. I., Daum, P. H., Lee, Y., Senum, G. I., Springston, S. R., Wang, J., Berkowitz, C., Hubbe, J., Zaveri, R. A., and Brechtel, F. J.: Aircraft observations of aerosol composition and ageing in New England and Mid-Atlantic States during the summer
2002 New England Air Quality Study field campaign, J. Geophys. Res., 112, D09310, doi:09310.01029/02006JD007786, 2007.

Lall, R. and Thurston, G. D.: Identifying and quantifying transported vs. local sources of New York City $\mathrm{PM}_{2.5}$ fine particulate matter air pollution, Atmos. Environ., 40, 333-346, 2006.

Lanz, V. A., Alfarra, M. R., Baltensperger, U., Buchmann, B., Hueglin, C., and Prévôt, A. S. H.: Source apportionment of submicron organic aerosols at an urban site by factor analytical modelling of aerosol mass spectra, Atmos. Chem. Phys., 7, 1503-1522, doi:10.5194/acp-7-1503-2007, 2007.

Liggio, J., Li, S.-M., Vlasenko, A., Sjostedt, S., Chang, R., Shantz, N., Abbatt, J., Slowik, J. G., Bottenheim, J. W., Brickell, P. C., Stroud, C., and Leaitch, W. R.: Primary and secondary organic aerosols in urban air masses intercepted at a rural site, J. Geophys. Res., 115, D21305, doi:10.1029/2010jd014426, 2010.

Massoli, P., Jayne, J., Fortner, E., Williams, L., Ng, N. L., Canagaratna, M., Onasch, T., Schwab, J., Demerjian, K., and Worsnop, D.: Temporal-spatial evolution and chemical characterization of particulate matter from vehicular exhaust near major roadways: results from the 2009 Queens College Air Quality study, AAAR 2010 Specialty Conference, San Diego, California, Abstract Number: 388, 2010.

Matthew, B. M., Middlebrook, A. M., and Onasch, T. B.: Collection Efficiencies in an Aerodyne Aerosol Mass Spectrometer as a Function of Particle Phase for Laboratory Generated Aerosols, Aerosol Sci. Tech., 42, 884-898, 2008.

McFiggans, G., Alfarra, M. R., Allan, J., Bower, K., Coe, H., Cubison, M., Topping, D., Williams, P., Decesari, S., Facchini, C., and Fuzzi, S.: Simplification of the representation of the organic component of atmospheric particulates, Faraday Discuss., 130, 341-362, 2005.

McLafferty, F. W., and Turecek, F.: Interpretation of Mass Spectra, University Science Books, Mill Valley, California, 1993.

Mohr, C., Huffman, J. A., Cubison, M. J., Aiken, A. C., Docherty, K. S., Kimmel, J. R., Ulbrich, I. M., Hannigan, M., and Jimenez, J. L.: Characterization of primary organic aerosol emissions from meat cooking, trash burning, and motor vehicles with HighResolution Aerosol Mass Spectrometry and comparison with ambient and chamber observations, Environ. Sci. Technol., 43, 2443-2449, doi:10.1021/es8011518, 2009.

Molina, M. J. and Molina, L. T.: Megacities and atmospheric pollution, J. Air Waste Manage., 54, 644-680, 2004.

Morgan, W. T., Allan, J. D., Bower, K. N., Highwood, E. J., Liu, D., McMeeking, G. R., Northway, M. J., Williams, P. I., Krejci, R., and Coe, H.: Airborne measurements of the spatial distribution of aerosol chemical composition across Europe and evolution of the organic fraction, Atmos. Chem. Phys., 10, 4065-4083, doi:10.5194/acp-10-4065-2010, 2010.

Müller, C., Iinuma, Y., Karstensen, J., van Pinxteren, D., Lehmann, S., Gnauk, T., and Herrmann, H.: Seasonal variation of aliphatic amines in marine sub-micrometer particles at the Cape Verde islands, Atmos. Chem. Phys., 9, 9587-9597, doi:10.5194/acp-99587-2009, 2009.

Ng, N. L., Canagaratna, M. R., Zhang, Q., Jimenez, J. L., Tian, J., Ulbrich, I. M., Kroll, J. H., Docherty, K. S., Chhabra, P. S., Bahreini, R., Murphy, S. M., Seinfeld, J. H., Hildebrandt, L., Donahue, N. M., DeCarlo, P. F., Lanz, V. A., Prévôt, A. S. H., Dinar, E., Rudich, Y., and Worsnop, D. R.: Organic aerosol 
components observed in Northern Hemispheric datasets from Aerosol Mass Spectrometry, Atmos. Chem. Phys., 10, 46254641, doi:10.5194/acp-10-4625-2010, 2010.

Paatero, P. and Tapper, U.: Positive matrix factorization: A nonnegative factor model with optimal utilization of error estimates of data values, Environmetrics, 5, 111-126, 1994.

Paatero, P., and Hopke, P. K.: Discarding or downweighting highnoise variables in factor analytic models, Anal. Chim. Acta, 490, 277-289, 2003

Polissar, A. V., Hopke, P. K., and Poirot, R. L.: Atmospheric aerosol over Vermont: Chemical composition and sources, Environ. Sci. Technol., 35, 4604-4621, 2001.

Pope, C. A., Burnett, R. T., Thun, M. J., Calle, E. E., Krewski, D., Ito, K., and Thurston, G. D.: Lung cancer, cardiopulmonary mortality, and long-term exposure to fine particulate air pollution, JAMA-J. Am. Med. Assoc., 287, 1132-1141, 2002.

Pope, C. A., Ezzati III, M., and Dockery, D. W.: Fine-particulate air pollution and life expectancy in the United States, N. Engl. J. Med., 360, 376-386, doi:10.1056/NEJMsa0805646, 2009.

Qin, Y., Kim, E., and Hopke, P. K.: The concentrations and sources of $\mathrm{PM}_{2.5}$ in metropolitan New York City, Atmos. Environ., 40, 312-332, 2006.

Quinn, P. K., Bates, T. S., Coffman, D., Onasch, T. B., Worsnop, D., Baynard, T., de Gouw, J. A., Goldan, P. D., Kuster, W. C., Williams, E., Roberts, J. M., Lerner, B., Stohl, A., Pettersson, A., and Lovejoy, E. R.: Impacts of sources and aging on submicrometer aerosol properties in the marine boundary layer across the Gulf of Maine, J. Geophys. Res., 111, D23S36, doi:10.1029/2006jd007582, 2006.

Rattigan, O. V., Felton, H. D., Bae, M.-S., Schwab, J. J., and Demerjian, K. L.: Multi-year hourly $\mathrm{PM}_{2.5}$ carbon measurements in New York: Diurnal, day of week and seasonal patterns, Atmos. Environ., 44, 2043-2053, 2010.

Remer, L. A., Kaufman, Y. J., Tanré, D., Mattoo, S., Chu, D. A., Martins, J. V., Li, R.-R., Ichoku, C., Levy, R. C., Kleidman, R. G., Eck, T. F., Vermote, E., and Holben, B. N.: The MODIS Aerosol Algorithm, Products, and Validation, J. Atmos. Sci., 62, 947-973, doi:10.1175/JAS3385.1, 2005.

Ren, X., Harder, H., Martinez, M., Lesher, R. L., Oliger, A., Shirley, T., Adams, J., Simpas, J. B., and Brune, W. H.: $\mathrm{HO}_{\mathrm{x}}$ concentrations and $\mathrm{OH}$ reactivity observations in New York City during PMTACS-NY2001, Atmos. Environ., 37, 3627-3637, 2003.

Rogge, W. F., Hildemann, L. M., Mazurek, M. A., Cass, G. R., and Simonelt, B. R. T.: Sources of fine organic aerosol .1. Charbroilers and meat cooking operations, Environ. Sci. Technol., 25, 1112-1125, 1991.

Rupakheti, M., Leaitch, W. R., Lohmann, U., Hayden, K., Brickell, P., Lu, G., Li, S.-M., Toom-Sauntry, D., Bottenheim, J. W., Brook, J. R., Vet, R., Jayne, J. T., and Worsnop, D. R.: An Intensive Study of the Size and Composition of Submicron Atmospheric Aerosols at a Rural Site in Ontario, Canada, Aerosol Sci. Tech., 39, 722-736, 2005.

Salcedo, D., Onasch, T. B., Dzepina, K., Canagaratna, M. R., Zhang, Q., Huffman, J. A., DeCarlo, P. F., Jayne, J. T., Mortimer, P., Worsnop, D. R., Kolb, C. E., Johnson, K. S., Zuberi, B., Marr, L. C., Volkamer, R., Molina, L. T., Molina, M. J., Cardenas, B., Bernabé, R. M., Márquez, C., Gaffney, J. S., Marley, N. A., Laskin, A., Shutthanandan, V., Xie, Y., Brune, W., Lesher, R., Shirley, T., and Jimenez, J. L.: Characterization of ambient aerosols in Mexico City during the MCMA-2003 campaign with Aerosol Mass Spectrometry: results from the CENICA Supersite, Atmos. Chem. Phys., 6, 925-946, doi:10.5194/acp-6-9252006, 2006.

Salcedo, D., Onasch, T. B., Aiken, A. C., Williams, L. R., de Foy, B., Cubison, M. J., Worsnop, D. R., Molina, L. T., and Jimenez, J. L.: Determination of particulate lead using aerosol mass spectrometry: MILAGRO/MCMA-2006 observations, Atmos. Chem. Phys., 10, 5371-5389, doi:10.5194/acp-10-53712010, 2010.

Schneider, J., Weimer, S., Drewnick, F., Borrmann, S., Helas, G., Gwaze, P., Schmid, O., Andreae, M. O., and Kirchner, U.: Mass spectrometric analysis and aerodynamic properties of various types of combustion-related aerosol particles, Int. J. Mass Spectrom., 258, 37-49, 2006.

Schwab, J. J., Felton, H. D., and Demerjian, K. L.: Aerosol chemical composition in New York state from integrated filter samples: Urban/rural and seasonal contrasts, J. Geophys. Res., 109, D16S05, doi:10.1029/2003jd004078, 2004.

Schwab, J. J., Bae, M.-S., Demerjian, K., Chen, W.-N., Lin, Y.C., Sun, Y., and Zhang, Q.: A Mobile Laboratory for On-Road and Near-Roadway Measurements of Fine Particulate Matter and Pollutant Gases, AAAR 2010 Specialty Conference, San Diego, California, Abstract 7SQ3.T2.101, 2010.

Seinfeld, J. H. and Pandis, S. N.: Atmospheric chemistry and physics: from air pollution to climate change, Wiley, John \& Sons, Incorporated, New York, 1203 pp., 2006.

Shilling, J. E., Chen, Q., King, S. M., Rosenoern, T., Kroll, J. H., Worsnop, D. R., DeCarlo, P. F., Aiken, A. C., Sueper, D., Jimenez, J. L., and Martin, S. T.: Loading-dependent elemental composition of $\alpha$-pinene SOA particles, Atmos. Chem. Phys., 9, 771-782, doi:10.5194/acp-9-771-2009, 2009.

lowik, J. G., Stainken, K., Davidovits, P., Williams, L. R., Jayne, J. T., Kolb, C. E., Worsnop, D. R., Rudich, Y., DeCarlo, P., and Jimenez, J. L.: Particle morphology and density characterization by combined mobility and aerodynamic diameter measurements. Part 2: Application to combustion generated soot particles as a function of fuel equivalence ratio, Aerosol Sci. Tech., 38, 12061222, 2004.

Slowik, J. G., Stroud, C., Bottenheim, J. W., Brickell, P. C., Chang, R. Y.-W., Liggio, J., Makar, P. A., Martin, R. V., Moran, M. D., Shantz, N. C., Sjostedt, S. J., van Donkelaar, A., Vlasenko, A., Wiebe, H. A., Xia, A. G., Zhang, J., Leaitch, W. R., and Abbatt, J. P. D.: Characterization of a large biogenic secondary organic aerosol event from eastern Canadian forests, Atmos. Chem. Phys., 10, 2825-2845, doi:10.5194/acp-10-2825-2010, 2010.

Sorooshian, A., Brechtel, F. J., Ma, Y., Weber, R. J., Corless, A., Flagan, R. C., and Seinfeld, J. H. Modeling and characterization of a Particle-into-Liquid Sampler (PILS), Aerosol Sci. Tech., 40, 396-409, 2006.

Sueper, D.: ToF-AMS Analysis Software, available at : http://cires.colorado.edu/jimenez-group/ToFAMSResources/ ToFSoftware/index.html, 2010.

Sun, Y., Zhang, Q., Macdonald, A. M., Hayden, K., Li, S. M., Liggio, J., Liu, P. S. K., Anlauf, K. G., Leaitch, W. R., Steffen, A., Cubison, M., Worsnop, D. R., van Donkelaar, A., and Martin, R. V.: Size-resolved aerosol chemistry on Whistler Mountain, Canada with a high-resolution aerosol mass spectrometer during INTEX-B, Atmos. Chem. Phys., 9, 3095-3111, doi:10.5194/acp- 
9-3095-2009, 2009.

Sun, J., Zhang, Q., Canagaratna, M. R., Zhang, Y., Ng, N. L., Sun, Y., Jayne, J. T., Zhang, X., Zhang, X., and Worsnop, D. R.: Highly time- and size-resolved characterization of submicron aerosol particles in Beijing using an Aerodyne Aerosol Mass Spectrometer, Atmos. Environ., 44, 131-140, 2010.

Sunder Raman, R., Hopke, P. K., and Holsen, T. M.: Carbonaceous aerosol at two rural locations in New York State: Characterization and behavior, J. Geophys. Res.-Atmos., 113, D12202, doi:12210.11029/12007JD009281, 2008.

Takegawa, N., Miyazaki, Y., Kondo, Y., Komazaki, Y., Miyakawa, T., Jimenez, J. L., Jayne, J. T., Worsnop, D. R., Allan, J. D., and Weber, R. J.: Characterization of an Aerodyne Aerosol Mass Spectrometer (AMS): Intercomparison with other aerosol Instruments, Aerosol Sci. Tech., 39, 760-770, 2005.

Takegawa, N., Miyakawa, T., Kondo, Y., Jimenez, J. L., Zhang, Q., Worsnop, D. R., and Fukuda, M.: Seasonal and diurnal variations of submicron organic aerosols in Tokyo observed using the Aerodyne Aerosol Mass Spectrometer (AMS), J. Geophys. Res., 111, D11206, doi:10.1029/2005JD006515, 2006.

Turpin, B. J. and Lim, H. J.: Species contributions to $\mathrm{PM}_{2.5}$ mass concentrations: Revisiting common assumptions for estimating organic mass, Aerosol Sci. Tech., 35, 602-610, 2001.

Ulbrich, I. M., Canagaratna, M. R., Zhang, Q., Worsnop, D. R., and Jimenez, J. L.: Interpretation of organic components from Positive Matrix Factorization of aerosol mass spectrometric data, Atmos. Chem. Phys., 9, 2891-2918, doi:10.5194/acp-9-2891-2009, 2009.

Venkatachari, P., Zhou, L., Hopke, P. K., Felton, D., Rattigan, O. V., Schwab, J. J., and Demerjian, K. L.: Spatial and temporal variability of black carbon in New York City, J. Geophys. Res., 111, D10S05, doi:10.1029/2005jd006314, 2006.

Weimer, S., Drewnick, F., Hogrefe, O., Schwab, J. J., Rhoads, K., Orsini, D., Canagaratna, M., Worsnop, D. R., and Demerjian, K. L.: Size-selective nonrefractory ambient aerosol measurements during the Particulate Matter Technology Assessment and Characterization Study-New York 2004 Winter Intensive in New York City, J. Geophys. Res., 111, D18305, doi:10.1029/2006JD007215, 2006.
Wexler, A. S. and Johnston, M. V.: What have we learned from highly time resolved measurements during the EPA supersite program and related studies?, J. Air Waste Manage., 58, 303319, 2008.

Zhang, Q., Alfarra, M. R., Worsnop, D. R., Allan, J. D., Coe, H., Canagaratna, M. R., and Jimenez, J. L.: Deconvolution and quantification of hydrocarbon-like and oxygenated organic aerosols based on aerosol mass spectrometry, Environ. Sci. Technol., 39, 4938-4952, doi:4910.1021/es0485681, 2005a.

Zhang, Q., Canagaratna, M. C., Jayne, J. T., Worsnop, D. R., and Jimenez, J. L.: Time and size-resolved chemical composition of submicron particles in Pittsburgh - Implications for aerosol sources and processes, J. Geophys. Res., 110, D07S09, doi:10.1029/2004JD004649, 2005b.

Zhang, Q., Worsnop, D. R., Canagaratna, M. R., and Jimenez, J. L.: Hydrocarbon-like and oxygenated organic aerosols in Pittsburgh: insights into sources and processes of organic aerosols, Atmos. Chem. Phys., 5, 3289-3311, doi:10.5194/acp-5-32892005, 2005c.

Zhang, Q., Jimenez, J. L., Canagaratna, M. R., Allan, J. D., Coe, H., Ulbrich, I., Alfarra, M. R., Takami, A., Middlebrook, A. M., Sun, Y. L., Dzepina, K., Dunlea, E., Docherty, K., DeCarlo, P. F., Salcedo, D., Onasch, T., Jayne, J. T., Miyoshi, T., Shimono, A., Hatakeyama, S., Takegawa, N., Kondo, Y., Schneider, J., Drewnick, F., Weimer, S., Demerjian, K., Williams, P., Bower, K., Bahreini, R., Cottrell, L., R.J.Griffin, Rautiainen, J., Sun, J. Y., Zhang, Y. M., and Worsnop, D. R.: Ubiquity and dominance of oxygenated species in organic aerosols in anthropogenicallyinfluenced northern hemisphere mid-latitudes, Geophys. Res. Lett., 34, L13801, doi:13810.11029/12007GL029979, 2007a.

Zhang, Q., Jimenez, J. L., Worsnop, D. R., and Canagaratna, M.: A case study of urban particle acidity and its effect on secondary organic aerosol, Environ. Sci. Technol., 41, 3213-3219, $2007 \mathrm{~b}$.

Zheng, M., Cass, G. R., Schauer, J. J., and Edgerton, E. S.: Source Apportionment of $\mathrm{PM}_{2.5}$ in the Southeastern United States Using Solvent-Extractable Organic Compounds as Tracers, Environ. Sci. Technol., 36, 2361-2371, 2002. 